NASA/TM-2005-213994

\title{
Small Portable PEM Fuel Cell Systems for NASA Exploration Missions
}

Kenneth A. Burke

Glenn Research Center, Cleveland, Ohio 
Since its founding, NASA has been dedicated to the advancement of aeronautics and space science. The NASA Scientific and Technical Information (STI) Program Office plays a key part in helping NASA maintain this important role.

The NASA STI Program Office is operated by Langley Research Center, the Lead Center for NASA's scientific and technical information. The NASA STI Program Office provides access to the NASA STI Database, the largest collection of aeronautical and space science STI in the world. The Program Office is also NASA's institutional mechanism for disseminating the results of its research and development activities. These results are published by NASA in the NASA STI Report Series, which includes the following report types:

- $\quad$ TECHNICAL PUBLICATION. Reports of completed research or a major significant phase of research that present the results of NASA programs and include extensive data or theoretical analysis. Includes compilations of significant scientific and technical data and information deemed to be of continuing reference value. NASA's counterpart of peerreviewed formal professional papers but has less stringent limitations on manuscript length and extent of graphic presentations.

- TECHNICAL MEMORANDUM. Scientific and technical findings that are preliminary or of specialized interest, e.g., quick release reports, working papers, and bibliographies that contain minimal annotation. Does not contain extensive analysis.

- CONTRACTOR REPORT. Scientific and technical findings by NASA-sponsored contractors and grantees.
- CONFERENCE PUBLICATION. Collected papers from scientific and technical conferences, symposia, seminars, or other meetings sponsored or cosponsored by NASA.

- SPECIAL PUBLICATION. Scientific, technical, or historical information from NASA programs, projects, and missions, often concerned with subjects having substantial public interest.

- TECHNICAL TRANSLATION. Englishlanguage translations of foreign scientific and technical material pertinent to NASA's mission.

Specialized services that complement the STI Program Office's diverse offerings include creating custom thesauri, building customized databases, organizing and publishing research results ... even providing videos.

For more information about the NASA STI Program Office, see the following:

- Access the NASA STI Program Home Page at http://www.sti.nasa.gov

- E-mail your question via the Internet to help@sti.nasa.gov

- Fax your question to the NASA Access Help Desk at 301-621-0134

- Telephone the NASA Access Help Desk at 301-621-0390

- Write to:

NASA Access Help Desk

NASA Center for AeroSpace Information 7121 Standard Drive

Hanover, MD 21076 
NASA/TM-2005-213994

\section{Small Portable PEM Fuel Cell Systems for NASA Exploration Missions}

Kenneth A. Burke

Glenn Research Center, Cleveland, Ohio

Prepared for the

Third International Energy Conversion Engineering Conference

sponsored by the American Institute of Aeronautics and Astronautics

San Francisco, California, August 15-18, 2005

National Aeronautics and

Space Administration

Glenn Research Center 


\section{Acknowledgments}

The author wishes to thank Thomas Tomsik, Glenn Research Center, for his analysis of cryogenic and supercritical reactant storage.

Available from

NASA Center for Aerospace Information 7121 Standard Drive

Hanover, MD 21076
National Technical Information Service 5285 Port Royal Road Springfield, VA 22100

Available electronically at http:/ /gltrs.grc.nasa.gov 


\title{
Small Portable PEM Fuel Cell Systems for NASA Exploration Missions
}

\author{
Kenneth A. Burke \\ National Aeronautics and Space Administration \\ Glenn Research Center \\ Cleveland, Ohio 44135
}

\begin{abstract}
The exploration of the Moon and Mars, whether by manned or unmanned spacecraft, will need portable power sources. Diverse manned and unmanned exploration will be done at greater distances from the initial landing sites and require greater amounts of power for spacesuits, portable tools, manned and unmanned rovers, as well as equipment used for construction and remote in-situ resource utilization. The energy-rich environment envisioned for these new missions will push the limits of state of the art battery technology because greater amounts of power for longer periods of operation are required while the mass and volume allotted for power sources will need to remain the same or be decreased.

Oxygen-Hydrogen PEM-based fuel cell systems are being examined as a portable power source in addition to advanced battery technology. Fuel cell power systems have been used by the Gemini, Apollo, and Space Shuttle programs. These systems have not been portable, but have been integral parts of their spacecraft, and have used reactants from a separate cryogenic supply. These systems typically have been higher in power. They also have had significant ancillary equipment sections that perform the pumping of reactants and coolant through the fuel cell stack and the separation of the product water from the unused reactant streams. The design of small portable fuel cell systems will be a significant departure from these previous designs. These smaller designs will have very limited ancillary equipment, relying on passive techniques for reactant and thermal management, and the reactant storage could be an integral part of the fuel cell system.

This paper is an analysis of the mass and volume of oxygen-hydrogen PEM fuel cell systems that was performed to evaluate fuel cell technology as an alternative to batteries for small portable power applications, and to quantify areas of technological improvement. An assessment of current fuel cell technology and reactant storage and management technology was completed to validate the analysis and to identify technology challenges.

This preliminary study indicates that fuel cell systems have the potential for energy densities of $>400 \mathrm{~W}-\mathrm{hr} / \mathrm{kg}$ and $>150 \mathrm{~W}$-hr/liter. This level of performance makes fuel cells attractive as portable high-power density, highenergy density sources for exploration missions.
\end{abstract}

\section{Introduction}

The purpose of this study was to expand on previous analyses of the mass and volume characteristics of fuel cell systems, ${ }^{1,2}$ and in particular look specifically at smaller power fuel cell systems that could potentially be used for Lunar and Mars portable power exploration applications. Part of this study is an initial assessment of storage techniques for the hydrogen and oxygen used by the fuel cell system.

\section{Background}

The heart of a fuel cell is an electrochemical "cell" that combines a fuel and an oxidizing agent, and converts the chemical energy directly into electrical power. A "stack" of cells is usually employed in applications. For this paper, only primary fuel cells are considered. Primary fuel cells like primary batteries are not electrically rechargeable; however unlike primary batteries, primary fuel cells are capable of being "recharged" by simply refilling the reactant storage tanks. This allows the primary fuel cell to continue to produce power. Secondary fuel cells (also referred to as regenerative fuel cells) use hydrogen and oxygen and produce water and electrical power. Secondary fuel cells like secondary batteries are rechargeable. To recharge a secondary fuel cell an external power source is used to electrolyze the water to replenish the hydrogen and oxygen. Figure 1 shows a conceptual diagram of primary and secondary fuel cells. 
Primary Fuel Cells

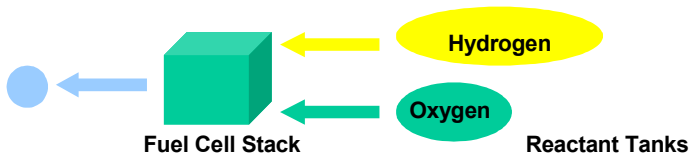

Secondary Fuel Cells

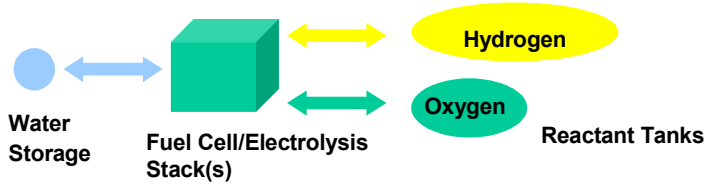

Figure 1. Primary and Secondary Fuel Cells
The amount of energy stored in the fuel and oxidant per unit mass is large compared to the energy stored in a typical battery. Unlike batteries, fuel cells generally do not store their fuel and oxidizer within the cell stack, but instead fuel and oxidizing agent are stored externally to the stack. Because of this characteristic, the energy capacity of a fuel cell power system is determined by the size of the fuel tanks, whereas the size of the fuel cell stack determines the power level. This situation is analogous to an automobile where the size of the fuel tank dictates how far you can drive, whereas the size of the automobile engine determines how fast you can drive. For space applications with long discharge times, the mass of the fuel cell and other process units is small compared to the mass of stored fuel, oxidant and tankage. This is the realm where fuel cells are most competitive on an energy per unit mass basis.

\section{Analysis of Small Portable Fuel Cells for Exploration Missions}

Fuel cells have been used for manned space vehicle power generation. These fuel cells have had power generation rates of 2 to 12 kilowatts and have used hydrogen and oxygen from cryogenic storage tanks. This analysis, while applicable to high power fuel cells, was done to address fuel cell systems within a power generation range of 0.1 to 1 kilowatt and discharge times of 24 hours or less. These types of primary fuel cell systems are envisioned to potentially play a role in portable power generation for exploration. The kinds of portable power applications are for use on small unmanned rovers, light construction equipment, small re-locatable power systems, and power for astronaut suits. Unlike previously used fuel cell systems where the fuel tanks were not refilled, the hydrogen and oxygen tanks of these small fuel cell systems will be refilled multiple times. For the purpose of this study only Proton Exchange Membrane (PEM) fuel cell systems were analyzed.

Fuel cell systems were analyzed to determine key metrics. A previous analysis of fuel cells for space science applications ${ }^{2}$ took into account the reactants, the reactant containment and the fuel cell stack, but not any ancillary equipment. The method of reactant containment that was previously analyzed was limited to pressurized gas storage. This study expands on the previous study by including the mass and volume of ancillary equipment, and also by expanding the reactant storage methods to include options other than pressurized gases. The water produced during power generation was assumed to be collected and recycled by other exploration systems rather than vented to space.

\section{A. Fuel Cell System Mass Power Density and Energy Density}

One of the key comparison metrics for fuel cells is power density, measured in watts per kilogram. This is the power delivered by the fuel cell divided by the mass of the fuel cell.

$$
\rho_{\mathrm{P}}=\frac{\mathrm{P}}{\mathrm{M}_{\mathrm{F}}+\mathrm{M}_{\mathrm{S}}+\mathrm{M}_{\mathrm{T}}+\mathrm{M}_{\mathrm{A}}+\mathrm{M}_{\mathrm{I}}}
$$

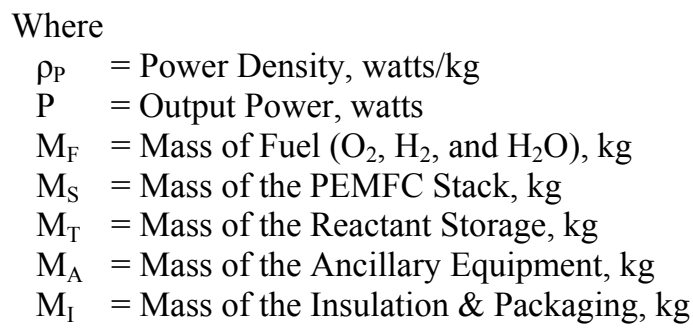


Rewriting the right-hand side of Eq. (1),

$$
\rho_{\mathrm{P}}=\frac{1}{\left(\frac{1}{\rho_{\mathrm{F}}}\right)+\left(\frac{1}{\rho_{\mathrm{S}}}\right)+\left(\frac{1}{\rho_{\mathrm{T}}}\right)+\left(\frac{1}{\rho_{\mathrm{A}}}\right)+\left(\frac{1}{\rho_{\mathrm{I}}}\right)}
$$

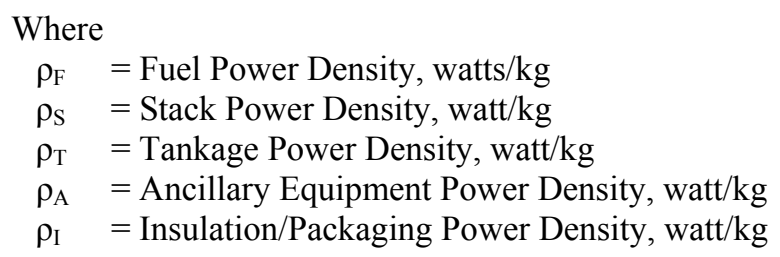

The appendix of this paper contains a detailed derivation of the mathematical expressions for the each of these power densities. The substitution of these mathematical expressions into Eq. (2) provides an overall expression of the power density of primary fuel cell systems using high pressure gaseous storage (which is Eq.(3)), or primary fuel cell systems using supercritical or cryogenic storage (which is Eq.(5)). The energy density of primary fuel cell systems is the fuel cell power density multiplied by the discharge time (Eq. (4) for high pressure gaseous storage or Eq.(6) for supercritical or cryogenic storage).

$$
\rho_{P}=\frac{1}{\left[1+\mathrm{k}_{\mathrm{I}}\right]\left[\left(\frac{\mathrm{t}_{\mathrm{d}}}{366 \eta_{\mathrm{e}}}\right)+\left(\frac{1}{\mathrm{~V}_{\mathrm{d}} \mathrm{I}_{\mathrm{d}} \mathrm{A}_{\mathrm{m}}}\right)+\left(\frac{\left[\frac{\mathrm{P}_{\mathrm{H}} \mathrm{V}_{\mathrm{M}, \mathrm{H}}}{\mu_{\mathrm{H}}}+\frac{\mathrm{P}_{\mathrm{O}} \mathrm{V}_{\mathrm{M}, \mathrm{O}}}{\mu_{\mathrm{O}}}+\frac{\mathrm{P}_{\mathrm{W}} \mathrm{V}_{\mathrm{M}, \mathrm{W}}}{\mu_{\mathrm{W}}}\right]}{65.898 \eta_{\mathrm{e}}}\right)+\mathrm{t}_{\mathrm{d}}\right)}
$$

$$
\rho_{\mathrm{E}}=\frac{\mathrm{t}_{\mathrm{d}}}{\left[1+\mathrm{k}_{\mathrm{I}}\right]\left[\left(\frac{\mathrm{t}_{\mathrm{d}}}{366 \mathrm{\eta}_{\mathrm{e}}}\right)+\left(\frac{1}{\mathrm{~V}_{\mathrm{d}} \mathrm{I}_{\mathrm{d}} \mathrm{A}_{\mathrm{m}}}\right)+\left(\frac{\left[\frac{\mathrm{P}_{\mathrm{H}} \mathrm{V}_{\mathrm{M}, \mathrm{H}}}{\mu_{\mathrm{H}}}+\frac{\mathrm{P}_{\mathrm{O}} \mathrm{V}_{\mathrm{M}, \mathrm{O}}}{\mu_{\mathrm{O}}}+\frac{\mathrm{P}_{\mathrm{W}} \mathrm{V}_{\mathrm{M}, \mathrm{W}}}{\mu_{\mathrm{W}}}\right] \mathrm{t}_{\mathrm{d}}}{65.898 \eta_{\mathrm{e}}}\right]+\mathrm{k}_{\mathrm{A}}\right]}
$$

$$
\begin{gathered}
\rho_{\mathrm{P}}=\frac{1}{\left[1+\mathrm{k}_{\mathrm{I}}\right]\left[\left(\frac{\mathrm{t}_{\mathrm{d}}}{366 \mathrm{\eta}_{\mathrm{e}}}\right)+\left(\frac{1}{\mathrm{~V}_{\mathrm{d}} \mathrm{I}_{\mathrm{d}} \mathrm{A}_{\mathrm{m}}}\right)+\left(\frac{\mathrm{M}_{\mathrm{T}, \mathrm{H}}}{\mathrm{P}}+\frac{\mathrm{M}_{\mathrm{T}, \mathrm{O}}}{\mathrm{P}}+\frac{\mathrm{M}_{\mathrm{T}, \mathrm{W}}}{\mathrm{P}}\right)+\mathrm{k}_{\mathrm{A}}\right]} \\
\rho_{\mathrm{E}}=\frac{\mathrm{t}_{\mathrm{d}}}{\left[1+\mathrm{k}_{\mathrm{I}}\right]\left[\left(\frac{\mathrm{t}_{\mathrm{d}}}{366 \mathrm{\eta}_{\mathrm{e}}}\right)+\left(\frac{1}{\mathrm{~V}_{\mathrm{d}} \mathrm{I}_{\mathrm{d}} \mathrm{A}_{\mathrm{m}}}\right)+\left(\frac{\mathrm{M}_{\mathrm{T}, \mathrm{H}}}{\mathrm{P}}+\frac{\mathrm{M}_{\mathrm{T}, \mathrm{O}}}{\mathrm{P}}+\frac{\mathrm{M}_{\mathrm{T}, \mathrm{W}}}{\mathrm{P}}\right)+\mathrm{k}_{\mathrm{A}}\right]}
\end{gathered}
$$

\footnotetext{
Where

$\mathrm{A}_{\mathrm{m}}=$ Fuel cell active area per unit mass $\mathrm{m}^{2} / \mathrm{kg}$

$\mathrm{I}_{\mathrm{d}} \quad=$ Fuel cell discharge current density, $\mathrm{A} / \mathrm{m}^{2}$ of active area

$\mathrm{k}_{\mathrm{A}}=$ Ancillary Equip. Factor, dimensionless

$\mathrm{k}_{\mathrm{I}} \quad=$ Packaging/Insulation Factor, dimensionless

$\eta_{\mathrm{e}} \quad=$ Energy Conversion Efficiency, dimensionless

$\mathrm{P}_{\mathrm{H}}=$ Hydrogen Tank Burst Pressure, atm

$\mathrm{P}_{\mathrm{O}} \quad=$ Oxygen Tank Burst Pressure, atm
} 


$$
\begin{array}{ll}
\mathrm{P}_{\mathrm{W}} & =\text { Water Tank Burst Pressure, atm } \\
\mathrm{t}_{\mathrm{d}} & =\text { Discharge Time, } \mathrm{hr} \\
\mu_{\mathrm{H}} & =\text { Hydrogen Tank Figure-of-Merit, atm-liter } / \mathrm{kg} \\
\mu_{\mathrm{O}} & =\text { Oxygen Tank Figure-of-Merit, atm-liter } / \mathrm{kg} \\
\mu_{\mathrm{W}} & =\text { Water Tank Figure-of-Merit, atm-liter } / \mathrm{kg} \\
\mathrm{V}_{\mathrm{M}, \mathrm{H}} & =\text { Hydrogen Molar Volume, liter/gmole } \\
\mathrm{V}_{\mathrm{M}, \mathrm{O}} & =\text { Oxygen Molar Volume, liter/gmole } \\
\mathrm{V}_{\mathrm{M}, \mathrm{W}} & =\text { Water Molar Volume, liter/gmole }
\end{array}
$$

\section{B. Fuel Cell System Volumetric Power Density and Energy Density}

Expressions similar to that developed for mass were developed for volumetric power density and volumetric energy density. The volumetric power density for fuel cells can be expressed as:

$$
\gamma_{P}=\frac{P}{V_{T}+V_{S}+V_{A}+V_{I}+V_{V}}
$$

Where

$\gamma_{\mathrm{P}} \quad=$ Volumetric power density, watt/liter

$\mathrm{V}_{\mathrm{T}} \quad=$ Tankage volume, liter

$\mathrm{V}_{\mathrm{S}} \quad=$ Fuel cell stack volume, liter

$\mathrm{V}_{\mathrm{A}}=$ Ancillary Equipment volume, liter

$\mathrm{V}_{\mathrm{I}} \quad=$ Packaging/Insulation volume, liter

$\mathrm{V}_{\mathrm{V}}=$ Void Space volume, liter

Equation (7) can be rewritten as:

$$
\gamma_{\mathrm{P}}=\frac{1}{\left(\frac{1}{\gamma_{\mathrm{T}}}\right)+\left(\frac{1}{\gamma_{\mathrm{S}}}\right)+\left(\frac{1}{\gamma_{\mathrm{A}}}\right)+\left(\frac{1}{\gamma_{\mathrm{I}}}\right)+\left(\frac{1}{\gamma_{\mathrm{V}}}\right)}
$$

Where

$\gamma_{\mathrm{T}}=$ Tankage volumetric. power density, watt/liter

$\gamma_{\mathrm{S}}=$ Stack volumetric. power density, watt/liter

$\gamma_{\mathrm{A}}=$ Ancillary Equip volumetric. power density, watt/liter

$\gamma_{\mathrm{I}} \quad=$ Pack./Insulation volumetric. power density, watt/liter

$\gamma_{\mathrm{V}} \quad=$ Void Space volumetric. power density, watt/liter

The appendix of this paper contains a detailed derivation of the mathematical expressions for the each of these volumetric power densities. The substitution of these mathematical expressions into Eq. (8) provides an overall expression of the volumetric power density of primary fuel cell systems using high pressure gaseous storage (which is Eq. (9)), or primary fuel cell systems using supercritical or cryogenic storage (which is Eq. (11)). The volumetric energy density of primary fuel cell systems is the fuel cell volumetric power density multiplied by the discharge time (Eq. (10) for high pressure gaseous storage or Eq. (12) for supercritical or cryogenic storage).

$$
\gamma_{\mathrm{P}}=\frac{1}{\left[1+\mathrm{k}_{\mathrm{V}}\right]\left[\frac{\mathrm{t}_{\mathrm{d}}\left[\mathrm{V}_{\mathrm{M}, \mathrm{H}}\left(1+\frac{\mathrm{P}_{\mathrm{H}}}{\widetilde{\rho}_{\mathrm{T}, \mathrm{H}} \mu_{\mathrm{H}}}\right)+0.5 \mathrm{~V}_{\mathrm{M}, \mathrm{O}}\left(1+\frac{\mathrm{P}_{\mathrm{O}}}{\widetilde{\rho}_{\mathrm{T}, \mathrm{O}} \mu_{\mathrm{O}}}\right)+\mathrm{V}_{\mathrm{M}, \mathrm{W}}\left(1+\frac{\mathrm{P}_{\mathrm{W}}}{\widetilde{\rho}_{\mathrm{T}, \mathrm{W}} \mu_{\mathrm{W}}}\right)\right]}{65.898 \eta_{\mathrm{e}}}+\left(\frac{1}{\mathrm{~V}_{\mathrm{d}} \mathrm{I}_{\mathrm{d}} \mathrm{A}_{\mathrm{V}}}\right)+\left(\frac{1}{\rho_{\mathrm{A}} \widetilde{\rho}_{\mathrm{A}}}\right)+\left(\frac{1}{\rho_{\mathrm{I}} \widetilde{\rho}_{\mathrm{I}}}\right)\right]}
$$




$$
\begin{gathered}
\left.\gamma_{\mathrm{E}}=\frac{\mathrm{t}_{\mathrm{d}}\left[\mathrm{V}_{\mathrm{M}, \mathrm{H}}\left(1+\frac{\mathrm{P}_{\mathrm{H}}}{\tilde{\rho}_{\mathrm{T}, \mathrm{H}} \mu_{\mathrm{H}}}\right)+0.5 \mathrm{~V}_{\mathrm{M}, \mathrm{O}}\left(1+\frac{\mathrm{P}_{\mathrm{O}}}{\tilde{\rho}_{\mathrm{T}, \mathrm{O}} \mu_{\mathrm{O}}}\right)+\mathrm{V}_{\mathrm{M}, \mathrm{W}}\left(1+\frac{\mathrm{P}_{\mathrm{W}}}{\widetilde{\rho}_{\mathrm{T}, \mathrm{W}} \mu_{\mathrm{W}}}\right)\right]}{65.898 \eta_{\mathrm{e}}}+\left(\frac{1}{\mathrm{~V}_{\mathrm{d}} \mathrm{I}_{\mathrm{d}} \mathrm{A}_{\mathrm{V}}}\right)+\left(\frac{1}{\rho_{\mathrm{A}} \widetilde{\rho}_{\mathrm{A}}}\right)+\left(\frac{1}{\rho_{\mathrm{I}} \widetilde{\rho}_{\mathrm{I}}}\right)\right] \\
\gamma_{\mathrm{P}}=\frac{1}{\left.\left[1+\mathrm{k}_{\mathrm{V}}\right]\left[\frac{\mathrm{V}_{\mathrm{T}, \mathrm{H}}}{\mathrm{P}}+\frac{\mathrm{V}_{\mathrm{T}, \mathrm{O}}}{\mathrm{P}}+\frac{\mathrm{V}_{\mathrm{T}, \mathrm{W}}}{\mathrm{P}}\right]+\left(\frac{1}{\mathrm{~V}_{\mathrm{d}} \mathrm{I}_{\mathrm{d}} \mathrm{A}_{\mathrm{V}}}\right)+\left(\frac{1}{\rho_{\mathrm{A}} \widetilde{\rho}_{\mathrm{A}}}\right)+\left(\frac{1}{\rho_{\mathrm{I}} \widetilde{\rho}_{\mathrm{I}}}\right)\right]} \\
\gamma_{\mathrm{E}}=\frac{\mathrm{t}_{\mathrm{d}}}{\left.\left[1+\mathrm{k}_{\mathrm{V}}\right]\left[\frac{\mathrm{V}_{\mathrm{T}, \mathrm{H}}}{\mathrm{P}}+\frac{\mathrm{V}_{\mathrm{T}, \mathrm{O}}}{\mathrm{P}}+\frac{\mathrm{V}_{\mathrm{T}, \mathrm{W}}}{\mathrm{P}}\right]+\left(\frac{1}{\mathrm{~V}_{\mathrm{d}} \mathrm{I}_{\mathrm{d}} \mathrm{A}_{\mathrm{V}}}\right)+\left(\frac{1}{\rho_{\mathrm{A}} \widetilde{\rho}_{\mathrm{A}}}\right)+\left(\frac{1}{\rho_{\mathrm{I}} \widetilde{\rho}_{\mathrm{I}}}\right)\right]}
\end{gathered}
$$

Where

$\mathrm{A}_{\mathrm{v}} \quad=$ Fuel cell active area per unit volume, $\mathrm{m}^{2} /$ liter

$\mathrm{k}_{\mathrm{V}}=$ Void Space Factor, dimensionless

$\widetilde{\rho}_{\mathrm{A}}=$ Mean Material density of ancillary equipment, $\mathrm{kg} / \mathrm{liter}$

$\tilde{\rho}_{\mathrm{I}}=$ Mean material density of packaging/insulation, $\mathrm{kg} / \mathrm{liter}$

$\widetilde{\rho}_{\mathrm{T}, \mathrm{H}}=$ Hydrogen tank material mean density, $\mathrm{kg} / \mathrm{liter}$

$\widetilde{\rho}_{\mathrm{T}, \mathrm{O}}=$ Oxygen tank material mean density, $\mathrm{kg} / \mathrm{liter}$

$\widetilde{\rho}_{\mathrm{T}, \mathrm{W}}=$ Water tank material mean density, $\mathrm{kg} / \mathrm{liter}$

$\gamma_{\mathrm{E}}=$ Volumetric fuel cell energy density, watt-hr/liter

\section{Performance Parameter Assessment}

Many of the variables in Eqs. (3) to (6) and (9) to (12) can generally be described as performance parameters which are measures of the status of technology development. Part of this analysis was an assessment of what numerical values for each of these performance parameters could be used to credibly assess the potential of primary fuel cell systems for portable power exploration applications.

\section{Fuel Cell Performance}

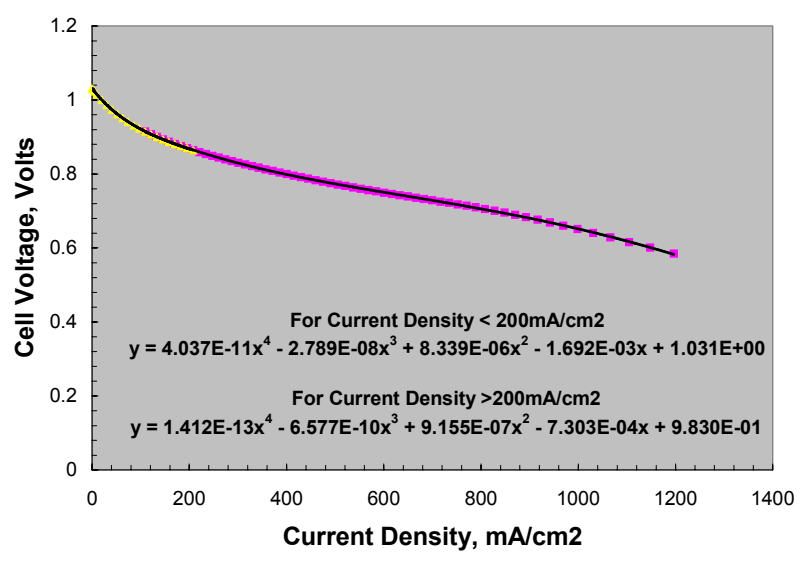

Figure 2 Fuel Cell Polarization Performance
The fuel cell polarization performance that was used in the analysis is shown in Figure 2. The curve is generally reflective of high performance hydrogenoxygen PEM fuel cells, but is not intended to reflect the performance of any single fuel cell manufacturer. The energy efficiency of the fuel cell is the product of both the voltage efficiency and the current efficiency, but the current efficiency is generally very close to 100 percent except when fuel cells are operated at high internal pressure or when the ion exchange membrane is compromised. For this analysis the current efficiency was assumed to be $100 \%$. The voltage efficiency of the fuel cell was taken as the ratio of the discharge voltage to the theoretical reversible cell voltage of 1.229 volts. The 
performance curve shown in Figure 2 is based on an operating temperature of $80{ }^{\circ} \mathrm{C}$ and an operating internal pressure of $3.4 \mathrm{~atm}$ (50 psia). These conditions (or very similar conditions) are the conditions expected for portable fuel cell systems. Operating at lower temperatures and internal pressures will reduce the performance of fuel cells, but these variations were not addressed in this analysis. In section D of this paper plots were made of the fuel cell system power density and energy density where the energy efficiency of the fuel cell was varied to illustrate the sensitivity of the power and energy density to this parameter. In other cases where other parameters were varied a efficiency value of 0.65 was used as a representative efficiency.

Besides the electrochemical performance, the fuel cell stack's power density is strongly affected by the efficiency of its construction. Two performance parameters were defined to quantify this construction efficiency. These quantify the cell stack active area per kilogram of stack mass $\left(\mathrm{A}_{\mathrm{m}}\right)$ and the cell stack active area per liter of stack volume $\left(A_{v}\right)$. The greater the numerical value for these parameters, the greater the efficiency of construction. The best examples of low mass and low volume construction found by the author are listed in Table 1 (Refs. 3 to 7). Each of the examples are PEM hydrogen-air fuel cell stacks. While fuel cell systems for exploration will operate on hydrogen and pure oxygen, for the purposes of assessing stack construction, the assumption was made that the efficiency of construction of these hydrogen-air fuel cell stacks could be duplicated in a hydrogen-oxygen fuel cell stack. Most of the examples are for stacks producing $80 \mathrm{~kW}$ or greater, yet one example is for a stack producing $0.67 \mathrm{~kW}$ which is more in the power regime of interest for small portable fuel cell systems. In section $\mathrm{E}$ of this paper plots of the sensitivity of fuel cell system power density and energy density to variations in these two fuel cell parameters were made. In other cases where other parameters were varied values of $A_{m}=2000 \mathrm{~cm}^{2} / \mathrm{kg}$ and $A_{v}=2400 \mathrm{~cm}^{2} /$ liter were used as conservative estimates of light weight fuel cell stacks based on the data in Table 1 .

Table 1 Examples of Low Mass and Low Volume Fuel Cell Stack Construction

\begin{tabular}{|l|c|c|c|c|c|c|c|c|}
\hline \multicolumn{1}{|c|}{ Manufacturer } & Type & Power & Mass & Dimensions & Cells $^{\mathrm{a}}$ & Active Area $^{\mathrm{b}}$ & $\mathrm{A}_{\mathrm{m}}{ }^{\mathrm{c}}$ & $\mathrm{A}_{\mathrm{v}}{ }^{\mathrm{d}}$ \\
\hline & & $\mathrm{kW}$ & $\mathrm{kg}$ & $\mathrm{cm}$ & & $\mathrm{cm}^{2} / \mathrm{cell}^{2}$ & $\mathrm{~cm}^{2} / \mathrm{kg}$ & $\mathrm{cm}^{2} /$ liter \\
\hline $\begin{array}{l}\text { GM (HyWire) } \\
\text { GM/Hydrogenics }\end{array}$ & H2/Air & 94 & 100 & $47.2 \times 25.1 \times 49.6$ & 200 & $996^{(2)}$ & 1992 & 3390 \\
\hline Nuvera (2005) & 102 & 82 & $82 \times 50 \times 14$ & 640 & $560^{(2)}$ & 4371 & 6244 \\
\hline Nuvera (2006) & H2/Air & 80 & 115 & $90 \times 55 \times 21$ & $380^{(1)}$ & $924^{(2)}$ & 3027 & 2666 \\
\hline Ballard Power Systems & H2/Air & 80 & 80 & $90 \times 50 \times 21$ & $380^{(1)}$ & $840^{(2)}$ & 3990 & 2666 \\
\hline Manhattan Scientific & H2/Air & 0.67 & 0.78 & $100 \times 13.5^{\mathrm{e}}$ & $40^{(1)}$ & $63^{(2)}$ & 3231 & 2377 \\
\hline
\end{tabular}

\section{Reactant Storage Performance}

Three different methods of hydrogen and oxygen storage were included in the analysis; high pressure gaseous storage, supercritical fluid storage, and cryogenic storage. Table 2 lists the properties of hydrogen and oxygen for the high pressure, supercritical, and cryogenic conditions used in the analysis. For cryogenic storage the reactants are in a liquid phase with a gaseous phase above the liquid phase when in a gravitational field. This, not surprisingly,

${ }^{a}$ For the cell stacks where the number of cells was not available, the number of cells was estimated based on the nominal output voltage provided by the manufacturer or a photograph of the cell stack

${ }^{\mathrm{b}}$ Cell active area estimated based on 80 percent of cross sectional area

${ }^{c}$ Calculated based on the estimated total stack active area and the specified mass

${ }^{\mathrm{d}}$ Calculated based on the estimated total stack active area and the specified dimensions

${ }^{\mathrm{e}}$ Dimensions estimated from photograph 
is the lowest pressure and densest form of reactant storage which leads to the lowest volume and lightest weight fuel cell system. Cryogenic storage may not be well suited to portable fuel cell systems which are likely to experience accelerations that will cause sloshing of the stored reactant. This sloshing could make the control of this type of reactant system difficult. For other types of portable systems that would be set up and then remain stationary during their operation, cryogenic storage would likely be an optimal choice. Supercritical storage is the type of reactant storage used aboard the space shuttle. ${ }^{8}$ Unlike cryogenic storage, the reactants are in a single phase, and so would not be susceptible to accelerations or the lack of a gravitational field. The storage pressure for supercritical hydrogen and oxygen is far less than the high pressure storage; so that the supercritical storage vessels are lower in mass compared to their high pressure counterparts. Even though the molar volumes are comparable between supercritical storage and 400 atm high pressure gaseous storage, the supercritical tanks are somewhat greater in volume due to the insulation jacketing required by the low temperature storage. Lastly, since the portable fuel cell systems are reliant upon the ability to refill the reactant storage tanks, the choice of reactant storage method is obviously dependent on the other exploration site infrastructure, and that infrastructure choice may be driven by factors other than the use of portable fuel cells.

Table 2 Properties of Stored Hydrogen and Oxygen

\begin{tabular}{|c|c|c|c|c|c|c|}
\hline & \multicolumn{2}{|c|}{ High Pressure Storage } & \multicolumn{2}{|c|}{ Supercritical Storage $\mathrm{e}^{(\mathrm{f})}$} & \multicolumn{2}{|c|}{ Cryogenic Storage } \\
\hline Physical Property & Hydrogen & Oxygen & Hydrogen & Oxygen & Hydrogen & Oxygen \\
\hline Temperature, K & 300 & 300 & 32.8 & 155 & 20.1 & 90 \\
\hline Pressure, atm & 400 & 400 & 12.76 & 49.76 & 1 & 1 \\
\hline Molar Volume, liter/mole & 0.0781 & 0.0662 & 0.0290 & 0.0287 & 0.0282 & 0.0280 \\
\hline
\end{tabular}

(f) Molar volumes calculated based on data on space shuttle supercritical hydrogen and oxygen tanks.

Table 3 Examples of Low Mass Composite Wrapped Pressure Vessels

\begin{tabular}{|l|c|c|c|c|c|c|}
\hline \multicolumn{1}{|c|}{ Supplier } & Quality & Capacity & Burst Pressure & Mass & Liner & $\mu$ \\
\hline Hypercomp & & Liter & $\mathrm{atm}$ & $\mathrm{kg}$ & & $\mathrm{Atm}-$ liter $/ \mathrm{kg}$ \\
\hline Hypercomp & COTS & 3.2 & 1000 & 1.36 & $\mathrm{Al}$ & 2353 \\
\hline Hypercomp & SOTA & 1.3 & 1000 & 2.09 & Inconel & 622 \\
\hline Hypercomp & SOTA & 1.3 & 1000 & 0.95 & Inconel & 1368 \\
\hline Hypercomp & COTS & 25 & 1000 & 8.48 & $\mathrm{Al}$ & 2948 \\
\hline Hypercomp & COTS & 25 & 1000 & 16.65 & Inconel & 1502 \\
\hline Hypercomp & SOTA & 25 & 1000 & 6.31 & $\mathrm{Al}$ & 3962 \\
\hline Hypercomp & SOTA & 25 & 1000 & 9.48 & Inconel & 2637 \\
\hline Carleton & SOTA & 43.4 & 640 & 10.66 & $\mathrm{Al}$ & 2605 \\
\hline Carleton & SOTA & 22.6 & 970 & 9.89 & $\mathrm{Al}$ & 2217 \\
\hline
\end{tabular}

Table 3 lists examples of low mass composite wrapped pressure vessels for storing high pressure gaseous hydrogen and oxygen (Refs. 9 and 10). This type of tank construction typically uses a non-permeable metal liner which is wrapped with high strength carbon composite fiber embedded within an epoxy matrix. The performance parameter defined in this analysis for high pressure tanks is a figure-of-merit, $\mu$, which is the product of the tank capacity and burst pressure divided by the dry mass of the tank. Table 3 lists different quality pressure vessels. Commercial-offthe-shelf (COTS) pressure vessels differ from State-of-the-art (SOTA) pressure vessels primarily in the thickness of the metal liner used to construct the tanks. The thicker liners used for COTS hardware improves the cycle life of the tank at the expense of greater mass. The SOTA hardware reduces the thickness of this liner to reduce the mass at the expense of cycle life. The SOTA hardware is typically used in space applications which are very mass sensitive and 
are not expected to experience many pressure cycles. Aluminum liners are most commonly used for composite wrapped tanks because aluminum is light and easily shaped into liners. Inconel, while considerably heavier than aluminum is much better suited for high pressure oxygen storage because of its resistance to combustion in a high pressure, pure oxygen environment. In section $\mathrm{D}$ of this paper plots of the sensitivity of fuel cell system power density and energy density to variations in these pressure vessel parameters were made. In other cases where other parameters were varied values of $\mu_{\mathrm{H}}=2500 \mathrm{~atm}-\mathrm{liter} / \mathrm{kg}$ and $\mu_{\mathrm{O}}=1300 \mathrm{~atm}-\mathrm{liter} / \mathrm{kg}$ were used as representative of light weight pressure vessels, based on the data in Table 3. The maximum storage pressure and the safety factors were used to calculate the burst pressure of each of the storage tanks. The safety factor used for the hydrogen and oxygen composite wrapped pressure vessels was 1.5 . The density of the composite material used in the analysis was $1.80 \mathrm{gm} / \mathrm{cm}^{3}$ (Ref. 11)

The tank mass and tank volume associated with the supercritical fluid storage and the cryogenic storage was data generated internally at the NASA Glenn Research Center. Insulation for the tanks was included as part of the mass and volume of the tanks. The plots of that data are shown in the Appendix. These tanks were sized assuming a safety factor of 2.0, a $1.3 \mathrm{~cm}(0.5 \mathrm{in}$.) thick vacuum jacket filled with multilayer insulation, a five percent tank ullage, and a tank accessory mass equal to 25 percent of the total tank mass.

It was assumed that the water produced by the fuel cell system would be stored as a liquid. The molar volume for water is 0.018 liter/mole which is much lower than either hydrogen or oxygen. The fuel cell system was assumed to operate at relatively low pressure (3 atm or less), so the pressure of the stored water was also assumed to be similarly low pressure. Data for this type of water storage was obtained from beverage bottle manufacturers and is plotted in Table 4 (Ref. 12). The range of tank sizes goes up to 2 liters which represents about 4000 to 6000 watthours of fuel cell energy production. These types of bottles are often made of polyethylene terephthalate (PET) and have burst pressure of $10 \mathrm{~atm}$.

Table 4 Water Storage Pressure Vessels

\begin{tabular}{|c|c|c|c|c|c|c|}
\hline Supplier & Quality & Capacity & Burst Pressure & Mass & Material Density & $\mu_{\mathrm{W}}$ \\
\hline & & Liter & Atm & $\mathrm{Kg}$ & $\mathrm{kg}^{-1}$ liter $^{-1}$ & Atm-liter-kg $^{-1}$ \\
\hline Westbridge & COTS & 0.5 & 10 & .024 & 1.33 & 208 \\
\hline Westbridge & COTS & 1 & 10 & .036 & 1.33 & 278 \\
\hline Westbridge & COTS & 1.5 & 10 & .042 & 1.33 & 357 \\
\hline Westbridge & COTS & 2 & 10 & .053 & 1.33 & 377 \\
\hline
\end{tabular}

\section{Fuel Cell System Ancillary, Insulation/Packaging Performance}

The mass of the ancillary equipment for a fuel cell system is very difficult to rigorously estimate. For the purposes of this study the fuel cell system ancillary equipment was assumed to include all fluidic, electrical, and electronic equipment necessary for the fuel cell system to deliver power. It was assumed that any equipment associated with the control and use of the power produced by the fuel cell system was to be considered part of an overall electrical power system, and not as fuel cell system ancillary equipment.

There is little data to derive estimates for the constants $\mathrm{k}_{\mathrm{A}}$ (the ancillary equipment factor, $\mathrm{kg} / \mathrm{watt}$ ) and $\mathrm{k}_{\mathrm{I}}$ (the packaging/insulation factor, dimensionless). The data that was used comes from the space shuttle powerplant. The shuttle power plant produces a peak power of $12 \mathrm{~kW}$. It's mass is $122 \mathrm{~kg}$, of which, $73 \mathrm{~kg}$ is the combined mass of the three fuel cell substacks. The remaining $49 \mathrm{~kg}$ is the mass of the ancillary equipment, the insulation around the fuel cell substacks, and the supporting packaging structure. Since no further breakdown of the 49 kilograms was available, an estimate was made that the mass was evenly split between the ancillary equipment and the insulation/packaging (i.e., $24.5 \mathrm{~kg}$ of ancillary equipment and $24.5 \mathrm{~kg}$ of packaging/insulation). Based on this, $\mathrm{k}_{\mathrm{A}}$ would be approximately $0.002 \mathrm{~kg} /$ watt (or $24.5 \mathrm{~kg} / 12 \mathrm{~kW}$ ). Also, based on space shuttle powerplant, the packaging and insulation are estimated to be about $24.5 \mathrm{~kg} /(122-24.5)$ or about 25 percent of the combined fuel cell stack mass and ancillary equipment mass. It was assumed in the analysis that the 25 percent of the fuel cell stack, ancillary equipment, and reactant storage mass would comprise the total mass of insulation and packaging (i.e., $\mathrm{k}_{\mathrm{I}}=0.25$ ). For the supercritical and cryogenic tanks the insulation mass and volume were included as part of the tank mass and volume and not accounted for separately. The sensitivity of the fuel cell system power end energy density to these parameters was included as part of this analysis. 
Table 5 summarizes the values for the various constants that were assumed for this analysis.

\begin{tabular}{|c|c|c|c|c|c|}
\hline \multicolumn{6}{|c|}{ Table 5 Assumed Variable Values } \\
\hline Variable Symbol & Units & Value & Variable Symbol & Units & Value \\
\hline$A_{m}$ & $\mathrm{~cm} 2 / \mathrm{kg}$ & 2000 & $\widetilde{\rho}_{\mathrm{I}}$ & $\mathrm{kg} /$ liter & 0.60 \\
\hline Av & $\mathrm{cm} 2 /$ liter & 2400 & $\tilde{\rho}_{\mathrm{T}, \mathrm{H}}$ & $\mathrm{kg} /$ liter & 1.80 \\
\hline Id & $\mathrm{Amp} / \mathrm{cm} 2$ & 0.398 & $\tilde{\rho}_{\mathrm{T}, \mathrm{O}}$ & $\mathrm{kg} / \mathrm{liter}$ & 1.80 \\
\hline $\mathrm{k}_{\mathrm{A}}$ & $\mathrm{kg} / \mathrm{watt}$ & .002 & $\widetilde{\rho}_{\mathrm{T}, \mathrm{W}}$ & $\mathrm{kg} / \mathrm{liter}$ & 1.33 \\
\hline $\mathrm{k}_{\mathrm{I}}$ & - & 0.3 & $\mathrm{SF}_{\mathrm{H}}$ & - & 1.5 \\
\hline $\mathrm{k}_{\mathrm{V}}$ & - & 0.25 & $\mathrm{SF}_{\mathrm{O}}$ & - & 1.5 \\
\hline$\eta_{\mathrm{e}}$ & - & 0.65 & $\mathrm{SF}_{\mathrm{W}}$ & - & 1.5 \\
\hline $\mathrm{P}$ & watt & 200 & $\mathrm{~T}$ & $\mathrm{~K}$ & 300 \\
\hline $\mathrm{P}_{\mathrm{MOP}, \mathrm{H}}$ & atm & 400 & $\mu_{\mathrm{H}}$ & atm-liter/kg & 2500 \\
\hline $\mathrm{P}_{\mathrm{MOP}, \mathrm{O}}$ & atm & 400 & $\mu_{\mathrm{O}}$ & atm-liter $/ \mathrm{kg}$ & 1300 \\
\hline $\mathrm{P}_{\mathrm{MOP}, \mathrm{W}}$ & atm & 400 & $\mu_{\mathrm{W}}$ & atm-liter $/ \mathrm{kg}$ & 300 \\
\hline$\widetilde{\rho}_{\mathrm{A}}$ & $\mathrm{kg} /$ liter & 2.0 & $\mathrm{~V}_{\mathrm{d}}$ & Volt & 0.799 \\
\hline
\end{tabular}

\section{Fuel Cell System Power Density and Energy Density Analysis Results}

The power density of a $200 \mathrm{~W}$ nominal power fuel cell system is plotted in Figure 5 using Eqs. (3) and (5) and the performance parameters listed in Table 5. Curves are plotted for gaseous storage using different values for the fuel cell stack energy efficiency. Curves at 65 percent efficiency are also plotted using supercritical and cryogenic storage. The horizontal asymptote in each curve represents a situation where the fuel cell stack is the predominant mass component. This is because as the discharge time gets shorter and shorter the fuel cell stack mass stays the same while the reactant storage tanks get smaller and smaller. As the discharge time gets longer the power from the fuel cell stack stays the same while the mass of the reactant storage tanks gets larger so the overall power density eventually approaches zero. The effect of the different fuel cell energy efficiencies is most prominent at short discharge times where the stack mass is the predominant mass. The effect of the efficiency is best seen by looking at the family of curves for high pressure gaseous storage. As the efficiency increases the power density decreases. The reason for this is that in order to achieve greater efficiency the fuel cell stack must operate at lower current density, thus to achieve the same power level the active area must be increased which results in a bigger stack. The same power out of a larger and larger cell stack results in a lower and lower power density. It should also be noticed that as the discharge time gets longer the effect of fuel cell energy efficiency becomes smaller.

The energy density of a $200 \mathrm{~W}$ nominal power fuel cell system is plotted in Figure 6 using Eqs. (4) and (6) and the performance parameters listed in Table 5. Curves are plotted for gaseous storage using different values for the fuel cell stack energy efficiency. Curves at 65 percent efficiency are also plotted using supercritical and cryogenic storage. Each of the curves starts to plateau as

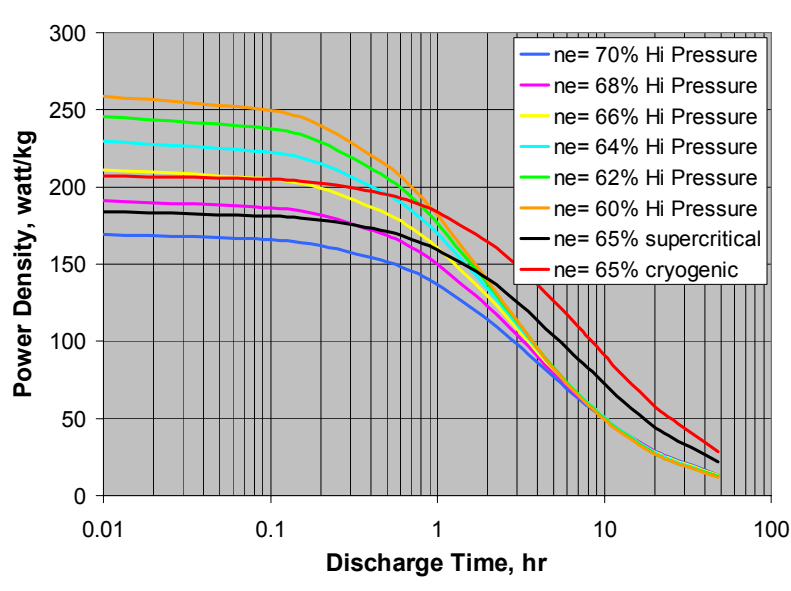

Figure 5 Power Density of Fuel Cell Systems

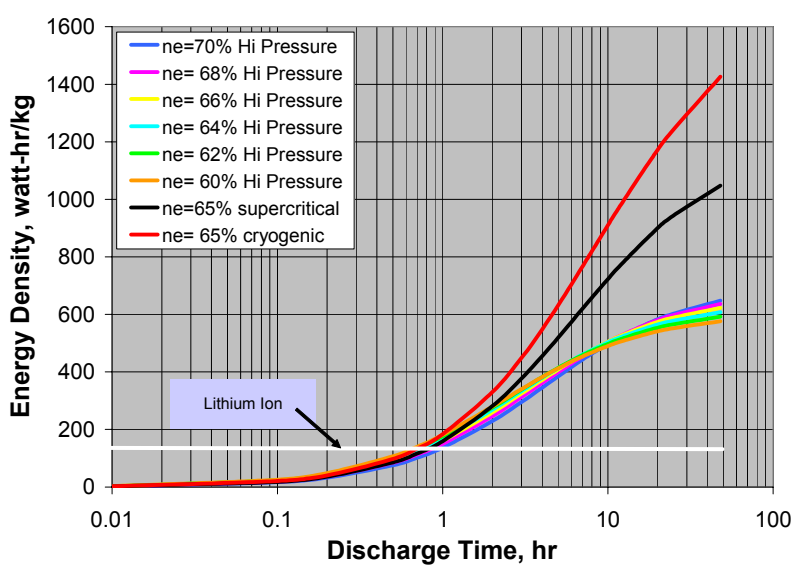

Figure 6 Energy Density of Fuel Cell Systems 
the discharge time gets longer and the reactant storage tanks are the predominant mass components. The differences between the three methods of reactant storage on energy density become prominent when the discharge times exceed a few hours with cryogenic storage being the most energy dense followed by supercritical storage and then high pressure gaseous storage. For the small portable fuel cell application where the discharge time exceeds a few hours the choice of fuel storage is of much greater consequence than the fuel cell stack efficiency. For discharge times between 2 and 24 hours a fuel cell system using cryogenic storage is between 60 and 120 percent more energy dense than one using high pressure gaseous storage. Similarly, supercritical storage is between 30 and 60 percent more energy dense than high pressure gaseous storage. The effect of the efficiency on energy density is best seen by looking at the family of curves for high pressure gaseous storage in Figure 6. At discharge times of less than 10 hours, as the efficiency increases, the energy density decreases. This effect is a reflection of the difference in fuel cell stack mass, with more efficient cell stacks being bigger. Beyond 10 hours, the effect of efficiency is reversed. Beyond 10 hours, the energy density increases as the efficiency increases for a given discharge time. This effect is a reflection of the difference in fuel mass out weighing the difference in fuel cell stack mass. The more efficient the fuel cell system, the less mass in fuel and storage tanks that is required which results in a more energy dense system. Figure 6 also shows that for discharge times exceeding two hours fuel cells appear capable of higher energy densities than state-of-the-art secondary lithium batteries which are $<150$ watt-hr $/ \mathrm{kg}$ ( Ref. 13 ).

Figure 7 plots energy density on the horizontal axis and power density on the vertical axis for a $200 \mathrm{~W}$ nominal power fuel cell system. This plot clearly shows the effect of discharge time on the energy and power density of fuel cells. As the discharge time gets longer and longer, the fuel cell stack mass has a negligible effect, the reactant storage tanks predominate and the energy density reaches a limit dictated by the performance of the reactant tanks. As the discharge time gets shorter and shorter, the reactant storage tankage mass becomes negligible, the fuel cell stack mass predominates, and the power density reaches a limit dictated by the performance of the fuel cell stack.

Figure 8 plots the volumetric power density of a 200W nominal power fuel cell system as a function of discharge time using Eq. (7). Curves are plotted for gaseous storage using different values for the fuel cell stack energy efficiency. Curves at 65 percent efficiency are also plotted using supercritical and cryogenic storage. As was the case with the mass analysis, the greatest volumetric power density occurs when the fuel cell stack, the power-producing component, occupies most of the volume. The volumetric power density is greatest when the fuel cell stack operates at the lowest efficiency (the highest current density) which makes the cell stack the smallest. As the discharge time gets longer, more and more of the volume is occupied by the reactant storage tankage, and the volumetric power density falls off.

Figure 9 plots the volumetric energy density of a 200W nominal power fuel cell system as a function of discharge time. Curves are plotted for gaseous storage using different values for the fuel cell stack energy efficiency. Curves at 65 percent efficiency are also

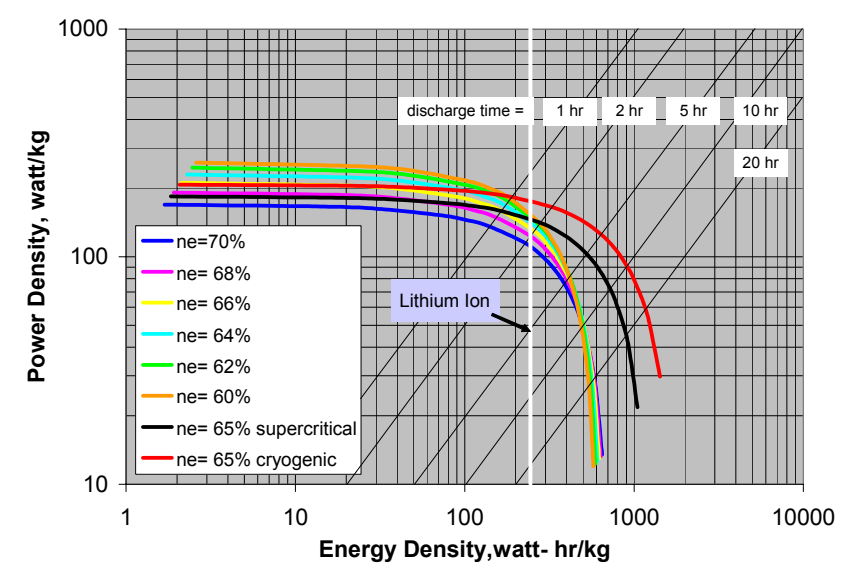

Figure 7 Energy Density versus Power Density

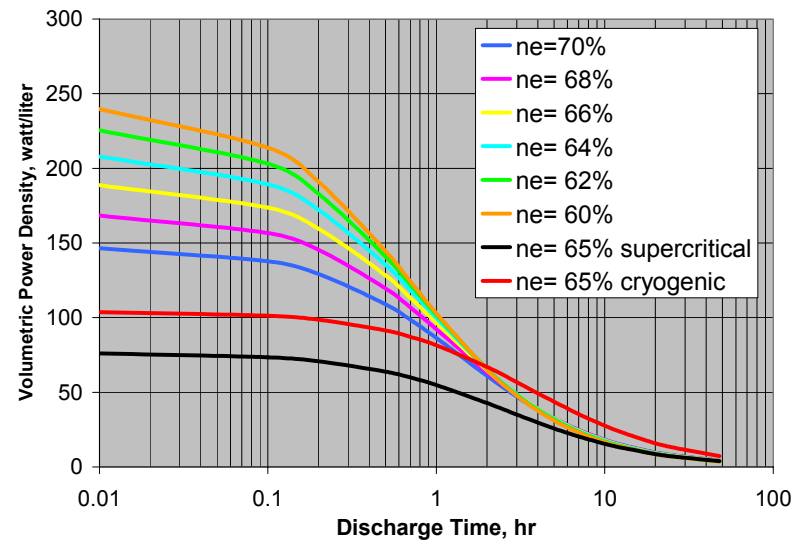

Figure 8 Fuel Cell System Volumetric Power Density

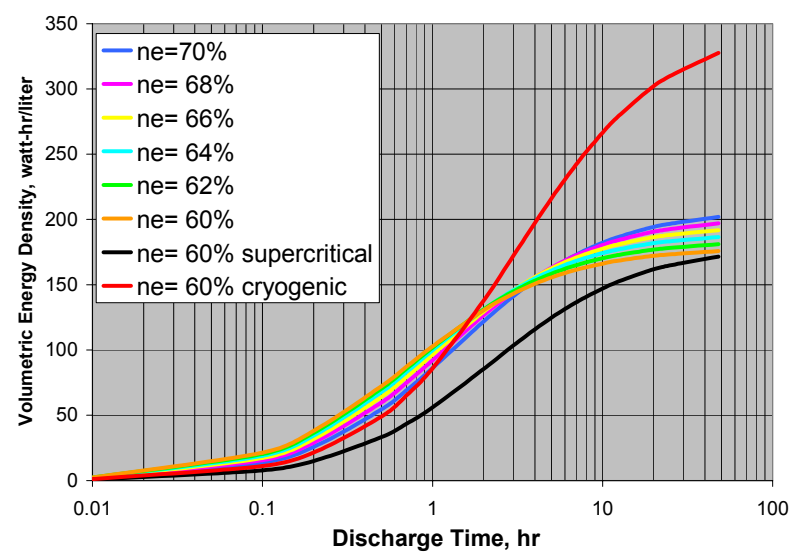

Figure 9 Fuel Cell System Volumetric Energy Density 
plotted using supercritical and cryogenic storage. As was the case with the mass analysis, as the discharge time gets longer and longer, the reactant tanks occupy more and more of the overall volume of the fuel cell. Since the reactant storage is the energy storage component, the volumetric energy density continues to increase. Figure 9 illustrate that at discharge times greater than 2 hours cryogenic storage has substantially better volumetric energy density than either of the other reactant storage methods. The supercritical storage, which clearly has mass energy density advantage over high pressure gaseous storage, does not have a similar advantage when comparing volumetric energy density. To the contrary, supercritical storage has a lower volumetric energy density (i.e., it will occupy more volume) than the high pressure gaseous storage option for discharge times less than 30 hours. This difference decreases as the discharge time gets longer (i.e., the storage tanks get larger) because supercritical storage has an advantage over high pressure gaseous storage when the molar volumes are compared (see Table 2). The effect of energy efficiency can be seen by looking at the family of curves for high pressure gaseous storage. At discharge times less than 3 hours the fuel cell system with the lowest efficiency (i.e., the smallest cell stack) has the greatest volumetric energy density, but beyond 5 hours the fuel cell system with the highest efficiency (i.e., the smallest reactant tanks) has the greatest volumetric energy density.

Figure 10 plots volumetric energy density on the horizontal axis and volumetric power density on the vertical axis for a $200 \mathrm{~W}$ nominal power fuel cell system. This plot shows that high pressure gaseous storage is generally more volume efficient than supercritical storage, but generally not as volume efficient as cryogenic storage when the discharge times exceed about 2 hours. The volumetric energy density of fuel cells using high pressure gaseous storage or supercritical storage is lower than state-of-the-art lithium batteries which have battery volumetric energy densities exceeding $200 \mathrm{watt}-\mathrm{hr} / \mathrm{liter}$ (Reference 13). The volumetric energy density of fuel cells with discharge times greater than 5 hours, and that use cryogenic storage is about equivalent to lithium ion batteries.

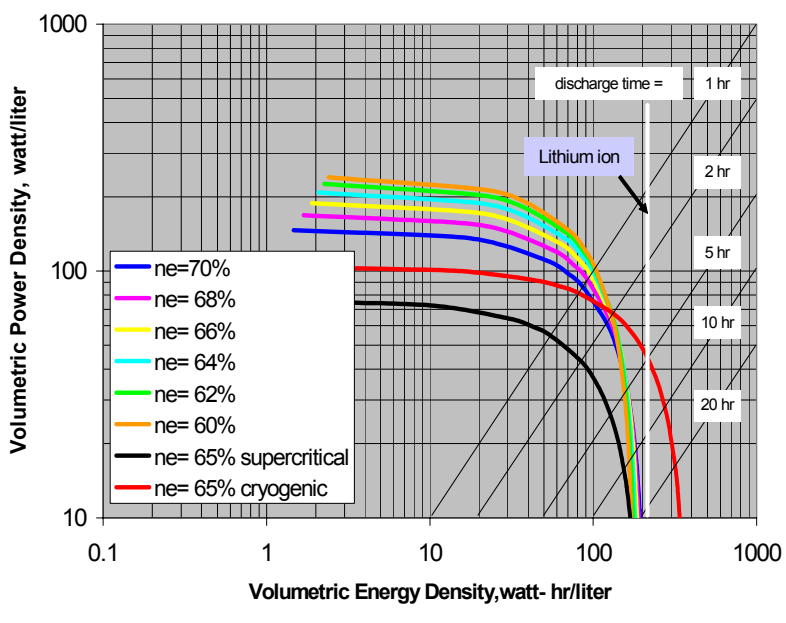

Figure 10 Volumetric Energy Density vs. Power Density

\section{E. Analysis Sensitivity Results}

In addition to obtaining the results using the assumed values for the performance parameters, plots were made using values of the performance parameters both higher and lower than those assumed in Table 5 . The purpose of this was to examine the sensitivity of the energy density to changes in performance parameters. Figures 11 and 12 plot the fuel cell power and energy density while varying the fuel cell stack performance parameters, $A_{m}$ and $A_{v}$. In both figures the middle yellow curve used the value of the performance parameter listed in Table 5. Figure 11 shows that for a variation of $A_{m}$ of 3 to 1 , and for a discharge time of 5 hours, the energy density varies from about 300 to 500 watt-hr/ $\mathrm{kg}$ (a variation of about 66 percent). Figure 12 shows that for a variation of $A_{v}$ of 3 to 1 , and for a

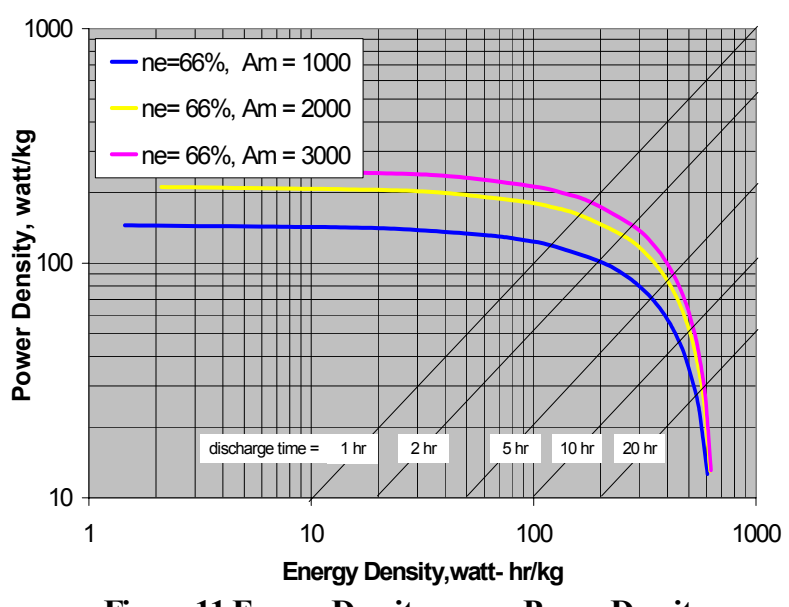

Figure 11 Energy Density versus Power Density

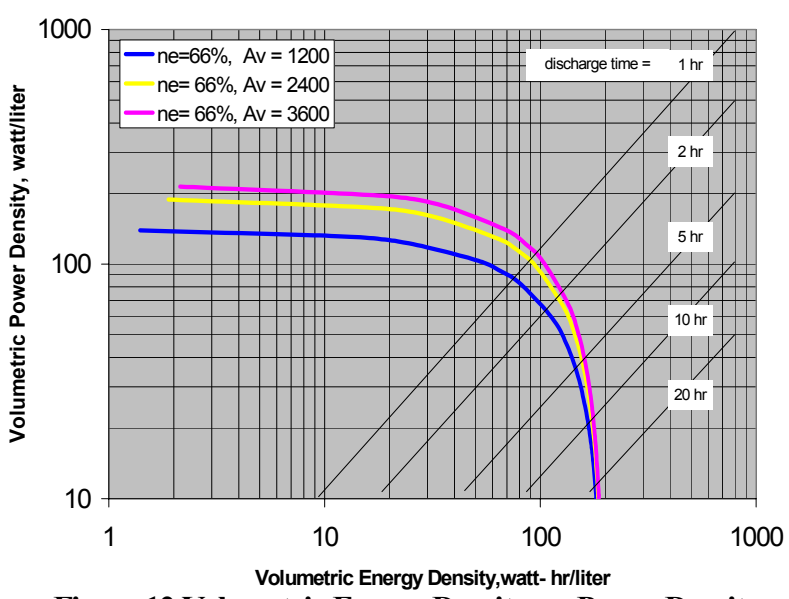

Figure 12 Volumetric Energy Density vs. Power Density 
discharge of 5 hours, the volumetric energy density varies from about 160 to 180 watt-hr/liter (a variation of about 10 percent). The reason that the volumetric energy density does not vary significantly is that the fuel cell stack does not occupy a significant overall percentage of the fuel cell system volume. The variation in $A_{m}$ has a greater effect because the fuel cell stack is a substantial portion of the overall percentage of the fuel cell system mass.

Figure 13 plots the fuel cell system power and energy density while varying the values used for the figure-ofmerit, $\mu$, for the high pressure hydrogen and oxygen tanks. The values for $\mu$ were varied \pm 25 percent from the nominal values listed in Table 2. As might be expected, the effects of variations in $\mu$ are most noticeable at discharge times exceeding 5 hours. For discharge times exceeding 5 hours each curve is "below the knee" and is on the more vertical asymptotic portion where the tankage mass is the predominant mass of the fuel cell system. For these longer discharge times it will be very important to have very efficient tank construction.

Figure 14 plots the fuel cell system power and energy density while varying the storage pressure of the high pressure reactant storage. The purpose of this plot was to examine the effect of the storage pressure on the volumetric power and energy density, and to relate these effects to the other reactant storage options. For discharge times exceeding 5 hours, cryogenic storage offers the lowest volume solution. For those very mobile portable power applications where cryogenic storage may not be workable, high pressure gaseous storage of 400 atmospheres or greater offers the next lowest volume solution. Supercritical storage offers the lowest volume solution for those applications unsuitable for cryogenic storage, the discharge time exceeds 5 hours, and where the reactant pressure is limited to 200 atmospheres or less. In general, cryogenic or high pressure gaseous storage offers the lowest volume solutions. For small portable power applications where cryogenic storage is not suitable, the choice between high pressure gaseous storage and supercritical storage appears to come down to a trade between mass and volume. If mass is more constrained, supercritical storage is favored. If volume is more constrained, high pressure gaseous storage is favored.

Figure 15 plots the power and energy density while varying the ancillary equipment performance parameter. Since there was little data available to address this portion of the fuel cell system, the purpose of this plot was to assess the effect that a substantial difference in the value of $k_{a}$ (the ancillary equipment factor) might have on the overall energy density of the fuel cell system. The value of $\mathrm{k}_{\mathrm{a}}$ is varied from 0.001 to $0.004 \mathrm{~kg} / \mathrm{watt}$. The impact of this $4: 1$ variation is most prominent at discharge times of less than 2 hours where the effect is a 30 percent or greater change. For discharge times of 5 hours or greater the effect on energy density is a 25 percent change or less. Until more data is available, this portion of the fuel cell system will continue to have the greatest uncertainty. Many of the portable power applications will have operational durations exceeding 5 hours so the impact of this uncertainty is less than if the operational time were 2 hours or less.

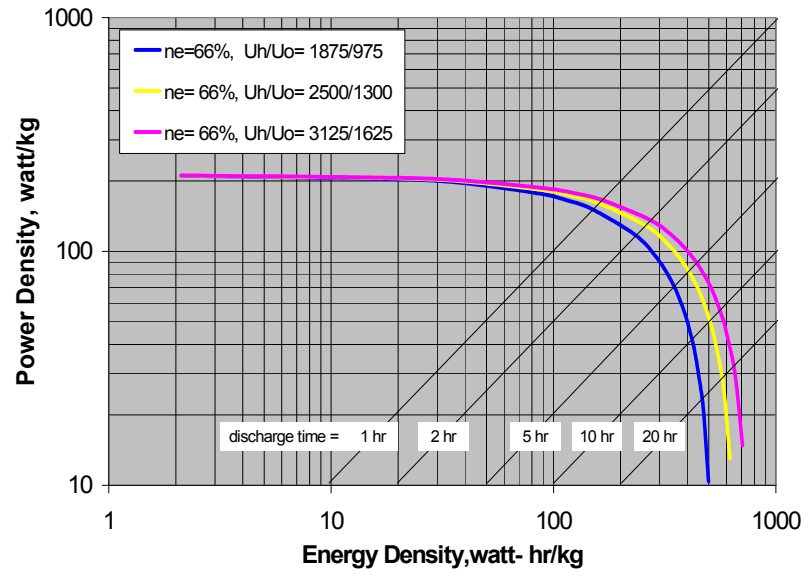

Figure 13 Energy Density versus Power Density

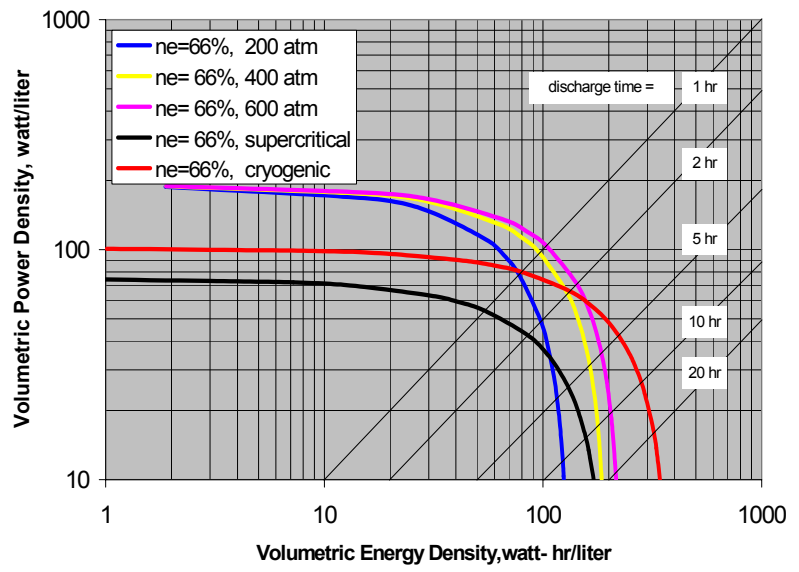

Figure 14 Volumetric Energy Density vs. Power Density

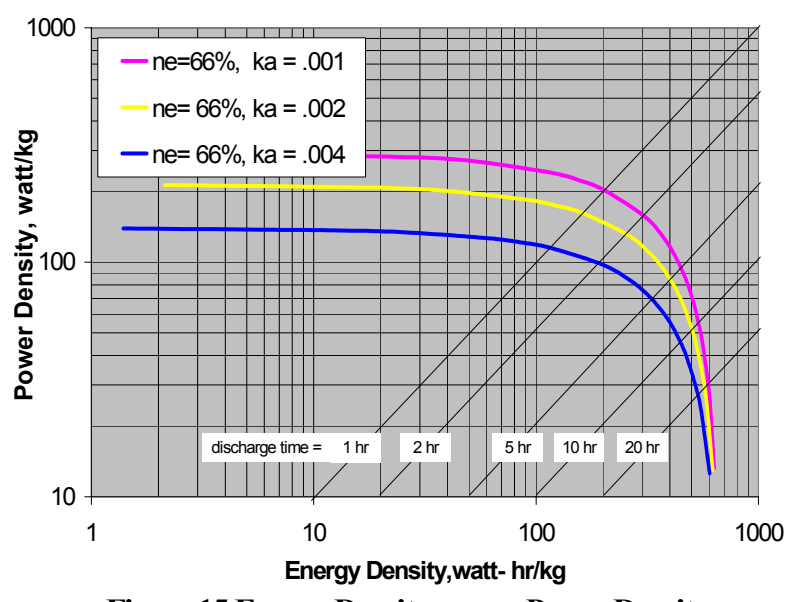

Figure 15 Energy Density versus Power Density 


\section{Conclusions}

The analysis of power density and energy density of fuel cells, lead to the following conclusions:

1) Hydrogen-oxygen PEM fuel cells appear to offer a lower mass approach than state-of-the-art batteries for portable power applications where the discharge time exceeds 2 to 3 hours. The mass savings will vary depending on the discharge time and the method of fuel cell reactant storage. This preliminary study indicates that fuel cell systems have the potential for energy densities of $>400 \mathrm{~W}-\mathrm{hr} / \mathrm{kg}$ when the discharge times exceed 3 to 5 hours. This level of performance makes fuel cells attractive as portable high-power density, high-energy density sources for exploration missions.

2) Hydrogen-oxygen PEM fuel cells using high pressure gaseous storage or supercritical storage occupy more volume than state-of-the-art batteries. A volumetric energy density of $>150 \mathrm{~W}$-hr/liter is possible for fuel cell systems using high pressure gaseous storage if the discharge time exceeds 3 hours. For fuel cell systems using cryogenic storage, if the discharge time exceeds 5 hours, the volumetric energy density is comparable to lithium ion batteries. The volumetric energy density will vary depending on the discharge time and the method of fuel cell reactant storage.

3) Cryogenic hydrogen and oxygen storage appears to be the most mass and volume efficient of the methods analyzed. Supercritical storage is more mass efficient than high pressure gaseous storage, but occupies more space than high pressure gaseous storage. The choice of reactant storage method will also depend on other factors such as cooling (supercritical and cryogenic storage could potentially offer some cooling whereas gaseous storage would not). Also cryogenic storage may not be compatible with systems anticipated to have accelerations that could cause "sloshing" of the liquid cryogens. Availability of the type of reactant on the lunar or Martian surface will also be a deciding factor.

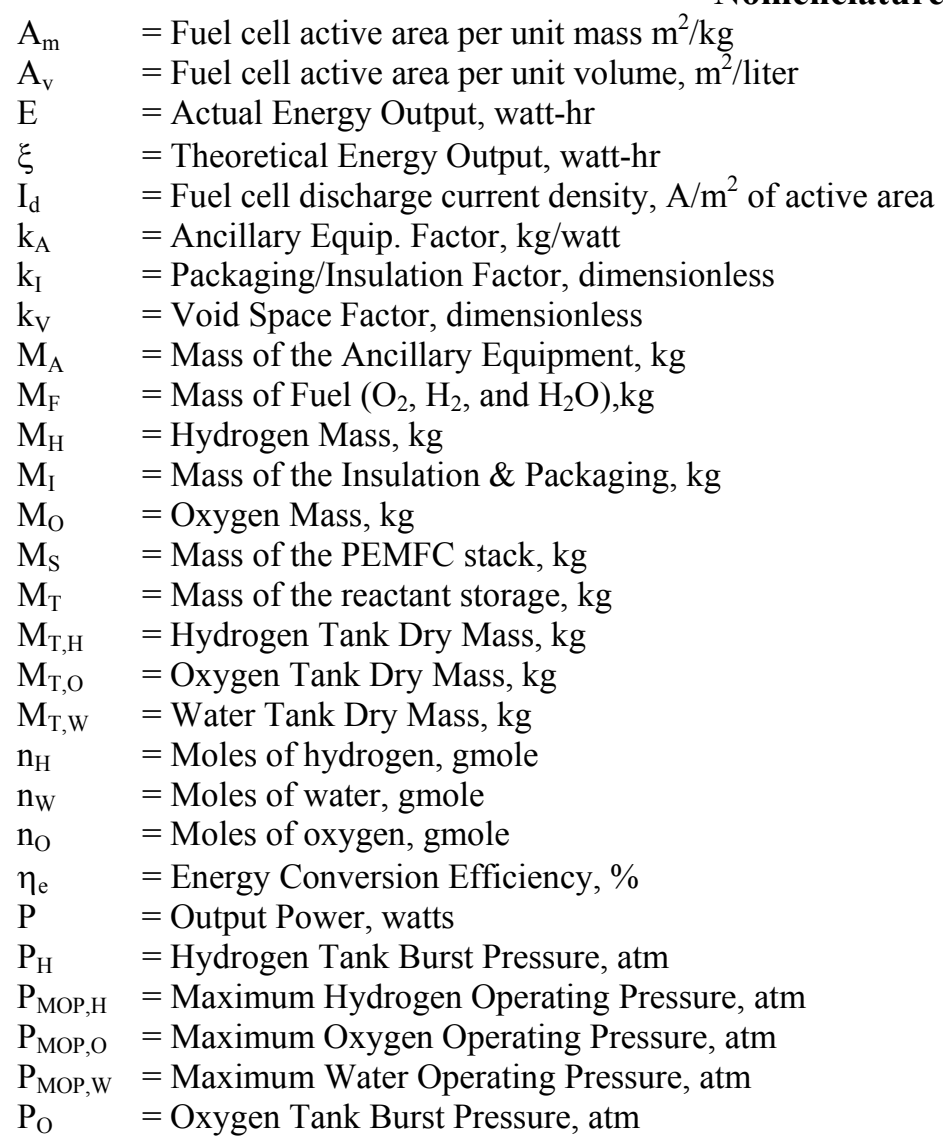




\begin{tabular}{|c|c|}
\hline $\mathrm{P}_{\mathrm{W}}$ & $=$ Water Tank Burst Pressure, atm \\
\hline$\rho_{\mathrm{A}}$ & $=$ Ancillary Equipment Power Density, watt $/ \mathrm{kg}$ \\
\hline$\rho_{\mathrm{E}}$ & $=$ Energy density, watt-hr/kg \\
\hline$\rho_{\mathrm{F}}$ & $=$ Fuel Power Density, watts $/ \mathrm{kg}$ of fuel \\
\hline$\rho_{\mathrm{I}}$ & $=$ Insulation $/$ Packaging Power Density, watt $/ \mathrm{kg}$ \\
\hline$\rho_{\mathrm{P}}$ & $=$ Power Density, watts $/ \mathrm{kg}$ \\
\hline$\rho_{\mathrm{S}}$ & $=$ PEMFC stack power density, watt $/ \mathrm{kg}$ of stack mass \\
\hline$\rho_{\mathrm{T}}$ & $=$ Reactant storage power density, watt $/ \mathrm{kg}$ \\
\hline$\tilde{\rho}_{\mathrm{A}}$ & $=$ Mean Material density of ancillary equipment, $\mathrm{kg} /$ liter \\
\hline$\tilde{\rho}_{\mathrm{I}}$ & $=$ Mean material density of packaging/insulation, $\mathrm{kg} /$ liter \\
\hline$\tilde{\rho}_{\mathrm{T}, \mathrm{H}}$ & $=$ Hydrogen tank material mean density, $\mathrm{kg} /$ liter \\
\hline$\tilde{\rho}_{\mathrm{T}, \mathrm{O}}$ & $=$ Oxygen tank material mean density, $\mathrm{kg} /$ liter \\
\hline$\tilde{\rho}_{\mathrm{T}, \mathrm{W}}$ & $=$ Water tank material mean density, $\mathrm{kg} /$ liter \\
\hline $\mathrm{SF}_{\mathrm{H}}$ & $=$ Hydrogen Tank Safety Factor, dimensionless \\
\hline $\mathrm{SF}_{\mathrm{O}}$ & $=$ Oxygen Tank Safety Factor, dimension \\
\hline $\mathrm{SF}_{\mathrm{W}}$ & $=$ Water Tank Safety Factor, dimensionless \\
\hline $\mathrm{T}$ & $=$ Gas temperature, $\mathrm{K}$ \\
\hline$t_{d}$ & harge Time, hr \\
\hline$\mu_{\mathrm{H}}$ & $=$ Hydrogen Tank Figure-of-Merit, atm-liter $/ \mathrm{kg}$ \\
\hline$\mu_{\mathrm{O}}$ & $=$ Oxygen Tank Figure-of-Merit, atm-liter $/ \mathrm{kg}$ \\
\hline$\mu_{\mathrm{W}}$ & $=$ Water Tank Figure-of-Merit, atm-liter $/ \mathrm{kg}$ \\
\hline $\mathrm{V}_{\mathrm{A}}$ & $=$ Ancillary Equipment volume, liter \\
\hline$V_{d}$ & $=$ Fuel cell discharge voltage, volts \\
\hline $\mathrm{V}_{\mathrm{H}}$ & $=$ Hydrogen Tank Volumetric Capacity, liter \\
\hline $\mathrm{V}_{\mathrm{I}}$ & $=$ Packaging/Insulation volume, liter \\
\hline $\mathrm{V}_{\mathrm{M}, \mathrm{H}}$ & $=$ Hydrogen Molar Volume, liter/gmole \\
\hline $\mathrm{V}_{\mathrm{M}, \mathrm{C}}$ & $=$ Oxygen Molar Volume, liter/gmole \\
\hline $\mathrm{V}_{\mathrm{M}, \mathrm{W}}$ & $=$ Water Molar Volume, liter/gmole \\
\hline $\mathrm{V}_{\mathrm{O}}$ & $=$ Oxygen Tank Volumetric Capacity, liter \\
\hline $\mathrm{V}_{\mathrm{S}}$ & $=$ Fuel cell stack volume, liter \\
\hline $\mathrm{V}_{\mathrm{T}}$ & $=$ Tankage volume, liter \\
\hline $\mathrm{V}_{\mathrm{T}, \mathrm{H}}$ & $=$ Hydrogen Tank Overall Volume, liter \\
\hline $\mathrm{V}_{\mathrm{T}, \mathrm{O}}$ & $=$ Oxygen Tank Overall Volume, liter \\
\hline $\mathrm{V}_{\mathrm{V}}$ & $=$ Void \\
\hline $\mathrm{V}_{\mathrm{W}}$ & Volumetric Capacity, liter \\
\hline$\gamma_{\mathrm{A}}$ & $=$ Ancillary Equip volumetric. power density, watt/liter \\
\hline$\gamma_{\mathrm{E}}$ & $=$ Volumetric fuel cell energy density, watt-hr/liter \\
\hline$\gamma_{\mathrm{I}}$ & $=$ Pack./Insulation volumetric. power density, watt/liter \\
\hline$\gamma_{P}$ & $=$ Fuel cell volumetric power density, watt/liter \\
\hline$\gamma_{\mathrm{S}}$ & $=$ Stack volumetric power density, watt/liter \\
\hline$\gamma_{T}$ & $=$ Tankage volumetric power density, watt/liter \\
\hline & $=$ Void Space volumetric. power density, watt/liter \\
\hline
\end{tabular}




\section{Appendix}

This appendix contains the detailed derivation of the expressions for the fuel cell system power and energy density used in the analysis.

\section{A. Fuel Cell System Power and Energy Density Based on Mass}

Fuel cell system power density that is based on mass is measured in watts per kilogram. This is the power delivered by the fuel cell system divided by the mass of the fuel cell system. The mass of the fuel cell system can be split between the fuel $\left(\mathrm{O}_{2}, \mathrm{H}_{2}\right.$, and $\left.\mathrm{H}_{2} \mathrm{O}\right)$, the PEMFC stack, the reactant storage, the ancillary equipment, and the insulation/packaging. The power density is expressed mathematically as:

$$
\rho_{P}=\frac{P}{M_{F}+M_{S}+M_{T}+M_{A}+M_{I}}
$$

Where

$\rho_{\mathrm{P}} \quad=$ Power Density, watts $/ \mathrm{kg}$

$\mathrm{P} \quad=$ Output Power, watts

$\mathrm{M}_{\mathrm{F}}=$ Mass of Fuel $\left(\mathrm{O}_{2}, \mathrm{H}_{2}\right.$, and $\left.\mathrm{H}_{2} \mathrm{O}\right), \mathrm{kg}$

$\mathrm{M}_{\mathrm{S}}=$ Mass of the PEMFC Stack, $\mathrm{kg}$

$\mathrm{M}_{\mathrm{T}}=$ Mass of the Reactant Storage, $\mathrm{kg}$

$\mathrm{M}_{\mathrm{A}}=$ Mass of the Ancillary Equipment, $\mathrm{kg}$

$\mathrm{M}_{\mathrm{I}}=$ Mass of the Insulation \& Packaging, $\mathrm{kg}$

Rewriting the right-hand side of Eq. (1),

$$
\rho_{\mathrm{P}}=\frac{1}{\left(\frac{1}{\rho_{\mathrm{F}}}\right)+\left(\frac{1}{\rho_{\mathrm{S}}}\right)+\left(\frac{1}{\rho_{\mathrm{T}}}\right)+\left(\frac{1}{\rho_{\mathrm{A}}}\right)+\left(\frac{1}{\rho_{\mathrm{I}}}\right)}
$$

Where

$$
\begin{aligned}
& \rho_{\mathrm{F}}=\text { Fuel Power Density, watts } / \mathrm{kg} \\
& \rho_{\mathrm{S}}=\text { Stack Power Density, watt } / \mathrm{kg} \\
& \rho_{\mathrm{T}}=\text { Tankage Power Density, watt } / \mathrm{kg} \\
& \rho_{\mathrm{A}}=\text { Ancillary Equipment Power Density, watt } / \mathrm{kg} \\
& \rho_{\mathrm{I}} \quad=\text { Insulation/Packaging Power Density, watt } / \mathrm{kg}
\end{aligned}
$$

The reason for writing Eq. (2) is that it is instructive to keep track of the individual contributions to the overall power density of each part of the fuel cell system.

\section{Fuel Power Density}

Using the quantity $E / t_{d}$ as the output power, the fuel power density can itself be rewritten as:

$$
\rho_{\mathrm{F}}=\frac{\mathrm{E}}{\mathrm{t}_{\mathrm{d}} \mathrm{M}_{\mathrm{F}}}
$$

Where

$\mathrm{E}=$ Actual Energy Output, watt-hr

$\mathrm{t}_{\mathrm{d}} \quad=$ Discharge Time, $\mathrm{hr}$ 
The actual energy output can be thought of as the product of the theoretical maximum energy output multiplied by the energy conversion efficiency.

$$
\mathrm{E}=\eta_{\mathrm{e}} \xi
$$

Where

$\xi \quad=$ Theoretical Energy Output, watt-hr

$\eta_{\mathrm{e}} \quad=$ Energy Conversion Efficiency, dimensionless

The symbol, $\eta_{\mathrm{e}}$ combines both voltage and current efficiency into a single energy conversion efficiency. Substituting Eq. (4) into equation (3) :

$$
\rho_{\mathrm{F}}=\frac{\eta_{\mathrm{e}} \xi}{\mathrm{t}_{\mathrm{d}} \mathrm{M}_{\mathrm{F}}}
$$

The quantity $\xi / \mathrm{M}_{\mathrm{F}}$ is the theoretical energy output per unit mass of fuel. For the $\mathrm{H}_{2} / \mathrm{O}_{2}$ fuel cell reaction the theoretical energy output per unit mass is 3661 watt-hr per $\mathrm{kg}$ of water formed (assuming 1.23 volts as the 100 percent voltage efficiency of the fuel cell). Substituting 3661 watt-hr per kg for the ratio $\xi / \mathrm{M}_{\mathrm{F}}$ :

$$
\rho_{\mathrm{F}}=\frac{3661 \eta_{\mathrm{e}}}{\mathrm{t}_{\mathrm{d}}}
$$

\section{Fuel Cell Stack Power Density}

The PEMFC stack power density can be expressed as:

$$
\rho_{\mathrm{S}}=\mathrm{V}_{\mathrm{d}} \mathrm{I}_{\mathrm{d}} \mathrm{A}_{\mathrm{m}}
$$

Where

$\mathrm{V}_{\mathrm{d}}=$ Discharge Voltage, volts

$\mathrm{I}_{\mathrm{d}} \quad=$ Discharge Current Density, amp $/ \mathrm{m}^{2}$

$\mathrm{A}_{\mathrm{m}}=$ Active Area per Unit Mass, $\mathrm{m}^{2} / \mathrm{kg}$

\section{Fuel Cell System Reactant Storage Power Density}

The reactant storage power density can be written as:

$$
\rho_{\mathrm{T}}=\frac{\mathrm{E}}{\mathrm{t}_{\mathrm{d}} \mathrm{M}_{\mathrm{T}}}=\frac{\eta_{\mathrm{e}} \xi}{\mathrm{t}_{\mathrm{d}} \mathrm{M}_{\mathrm{T}}}
$$

For most primary fuel cell systems the mass of the reactant storage is the mass of the hydrogen and oxygen tanks. Since the water is envisioned to be stored and ultimately recycled, the mass of the water tank is also then included in the mass of the reactant storage tank mass. The mass of reactant storage can be expressed as:

$$
\mathrm{M}_{\mathrm{T}}=\mathrm{M}_{\mathrm{T}, \mathrm{H}}+\mathrm{M}_{\mathrm{T}, \mathrm{O}}+\mathrm{M}_{\mathrm{T}, \mathrm{W}}
$$

Where

$\mathrm{M}_{\mathrm{T}, \mathrm{H}}=$ Hydrogen Tank Dry Mass, $\mathrm{kg}$

$\mathrm{M}_{\mathrm{T}, \mathrm{O}}=$ Oxygen Tank Dry Mass, $\mathrm{kg}$

$\mathrm{M}_{\mathrm{T}, \mathrm{W}}=$ Water Tank Dry Mass, $\mathrm{kg}$ 
The mass of these tanks can be estimated based on a figure of merit that relates the pressure, volume and dry mass of a state-of-the-art light-weight pressure vessel. For the hydrogen and oxygen tanks the figure of merit for each tank is:

$$
\begin{gathered}
\mu_{\mathrm{H}}=\frac{\mathrm{P}_{\mathrm{H}} \mathrm{V}_{\mathrm{H}}}{\mathrm{M}_{\mathrm{T}, \mathrm{H}}} \\
\mu_{\mathrm{O}}=\frac{\mathrm{P}_{\mathrm{O}} \mathrm{V}_{\mathrm{O}}}{\mathrm{M}_{\mathrm{T}, \mathrm{O}}} \\
\mu_{\mathrm{W}}=\frac{\mathrm{P}_{\mathrm{W}} \mathrm{V}_{\mathrm{W}}}{\mathrm{M}_{\mathrm{T}, \mathrm{W}}}
\end{gathered}
$$

Where

$\mu_{\mathrm{H}} \quad=$ Hydrogen Tank Figure-of-Merit, atm-liter $/ \mathrm{kg}$

$\mathrm{P}_{\mathrm{H}} \quad=$ Hydrogen Tank Burst Pressure, atm

$\mathrm{V}_{\mathrm{H}}=$ Hydrogen Tank Volumetric Capacity, liter

$\mu_{\mathrm{O}} \quad=$ Oxygen Tank Figure-of-Merit, atm-liter $/ \mathrm{kg}$

$\mathrm{P}_{\mathrm{O}} \quad=$ Oxygen Tank Burst Pressure, atm

$\mathrm{V}_{\mathrm{O}}=$ Oxygen Tank Volumetric Capacity, liter

$\mu_{\mathrm{W}}=$ Water Tank Figure-of-Merit, atm-liter $/ \mathrm{kg}$

$\mathrm{P}_{\mathrm{W}}=$ Water Tank Burst Pressure, atm

$\mathrm{V}_{\mathrm{W}}=$ Water Tank Volumetric Capacity, liter

The mass of the hydrogen, oxygen, and water tanks are expressed as:

$$
\begin{aligned}
& \mathrm{M}_{\mathrm{T}, \mathrm{H}}=\frac{\mathrm{P}_{\mathrm{H}} \mathrm{V}_{\mathrm{H}}}{\mu_{\mathrm{H}}} \\
& \mathrm{M}_{\mathrm{T}, \mathrm{O}}=\frac{\mathrm{P}_{\mathrm{O}} \mathrm{V}_{\mathrm{O}}}{\mu_{\mathrm{O}}} \\
& \mathrm{M}_{\mathrm{T}, \mathrm{W}}=\frac{\mathrm{P}_{\mathrm{W}} \mathrm{V}_{\mathrm{W}}}{\mu_{\mathrm{W}}}
\end{aligned}
$$

The storage tank burst pressure is related to the maximum operating pressure by a safety factor, expressed as:

Where

$$
\begin{aligned}
& \mathrm{P}_{\mathrm{H}}=\mathrm{SF}_{\mathrm{H}}\left(\mathrm{P}_{\mathrm{MOP}, \mathrm{H}}\right) \\
& \mathrm{P}_{\mathrm{O}}=\mathrm{SF}_{\mathrm{O}}\left(\mathrm{P}_{\mathrm{MOP}, \mathrm{O}}\right) \\
& \mathrm{P}_{\mathrm{W}}=\mathrm{SF}_{\mathrm{W}}\left(\mathrm{P}_{\mathrm{MOP}, \mathrm{W}}\right)
\end{aligned}
$$

$\mathrm{SF}_{\mathrm{H}} \quad=$ Hydrogen Tank Safety Factor, dimensionless

$\mathrm{SF}_{\mathrm{O}} \quad=$ Oxygen Tank Safety Factor, dimensionless

$\mathrm{SF}_{\mathrm{W}} \quad=$ Water Tank Safety Factor, dimensionless

$\mathrm{P}_{\mathrm{MOP}, \mathrm{H}}=$ Maximum Hydrogen Operating Pressure, atm

$\mathrm{P}_{\mathrm{MOP}, \mathrm{O}}=$ Maximum Oxygen Operating Pressure, atm

$\mathrm{P}_{\mathrm{MOP}, \mathrm{W}}=$ Maximum Water Operating Pressure, atm

The volumetric capacity of the hydrogen, oxygen and water tanks are expressed as:

$$
\begin{aligned}
& \mathrm{V}_{\mathrm{H}}=\mathrm{V}_{\mathrm{M}, \mathrm{H}} \mathrm{n}_{\mathrm{H}} \\
& \mathrm{V}_{\mathrm{O}}=\mathrm{V}_{\mathrm{M}, \mathrm{O}} \mathrm{n}_{\mathrm{O}}
\end{aligned}
$$




$$
\mathrm{V}_{\mathrm{W}}=\mathrm{V}_{\mathrm{M}, \mathrm{W}} \mathrm{n}_{\mathrm{W}}
$$

Where

$\mathrm{V}_{\mathrm{M}, \mathrm{H}}=$ Hydrogen Molar Volume, liter/gmole

$\mathrm{n}_{\mathrm{H}} \quad=$ Moles of Hydrogen, gmole

$\mathrm{V}_{\mathrm{M}, \mathrm{O}}=$ Oxygen Molar Volume, liter/gmole

$\mathrm{n}_{\mathrm{O}} \quad=$ Moles of Oxygen, gmole

$\mathrm{V}_{\mathrm{M}, \mathrm{W}}=$ Water Molar Volume, liter/gmole

$\mathrm{n}_{\mathrm{W}} \quad=$ Moles of Water, gmole

The molar volumes of hydrogen and oxygen are used because above 70 atmospheres of pressure the ideal gas law is not sufficiently accurate to model the pressure, volume, and temperature relationship.

The tanks are sized based upon the maximum required capacity. It was also assumed that the maximum number of moles of hydrogen to be stored is equal to the maximum moles of water to be stored. Similarly, the maximum moles of oxygen to be stored are equal to one-half the maximum moles of water to be stored. Expressing this mathematically,

$$
\mathrm{n}_{\mathrm{H}}=\mathrm{n}_{\mathrm{W}}=2 \mathrm{n}_{\mathrm{O}}
$$

Substituting Eqs. (13),(14),(15),(19),(20),(21), and (22) into Eq. (9),

$$
\mathrm{M}_{\mathrm{T}}=\left[\frac{\mathrm{P}_{\mathrm{H}} \mathrm{V}_{\mathrm{M}, \mathrm{H}}}{\mu_{\mathrm{H}}}+\frac{\mathrm{P}_{\mathrm{O}} \mathrm{V}_{\mathrm{M}, \mathrm{O}}}{2 \mu_{\mathrm{O}}}+\frac{\mathrm{P}_{\mathrm{W}} \mathrm{V}_{\mathrm{M}, \mathrm{W}}}{\mu_{\mathrm{W}}}\right] \mathrm{n}_{\mathrm{W}}
$$

The number of moles of water can be expressed as:

$$
\mathrm{n}_{\mathrm{W}}=\frac{\mathrm{M}_{\mathrm{F}}}{0.018 \mathrm{~kg} / \text { gmole }}
$$

When Eqs. (23) and (24) are substituted into Eq. (8) and the ratio of $\xi / \mathrm{M}_{\mathrm{F}}$ is set equal to $3661 \mathrm{watt}-\mathrm{hr} / \mathrm{kg}$, the simplified result is:

$$
\rho_{\mathrm{T}}=\frac{65.898 \eta_{\mathrm{e}}}{\left[\frac{\mathrm{P}_{\mathrm{H}} \mathrm{V}_{\mathrm{M}, \mathrm{H}}}{\mu_{\mathrm{H}}}+\frac{\mathrm{P}_{\mathrm{O}} \mathrm{V}_{\mathrm{M}, \mathrm{O}}}{2 \mu_{\mathrm{O}}}+\frac{\mathrm{P}_{\mathrm{W}} \mathrm{V}_{\mathrm{M}, \mathrm{W}}}{\mu_{\mathrm{W}}}\right] \mathrm{t}_{\mathrm{d}}}
$$

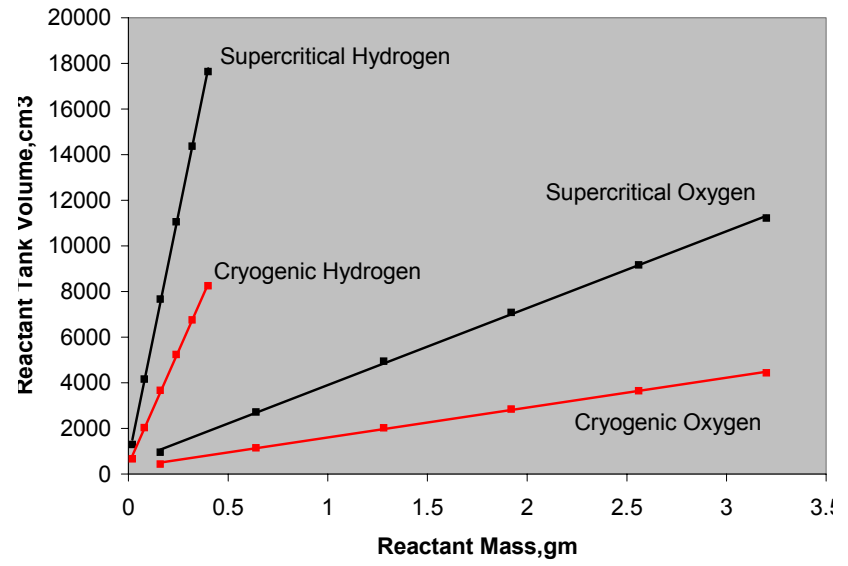

NASA/TM-2005-213994
The tank mass associated with the supercritical fluid storage and the cryogenic storage was data generated internally at the NASA Glenn Research Center. Insulation for the tanks was included as part of the mass and volume of the tanks. The plots of that data are shown in Figures A1. These tanks were sized assuming a safety factor of 2.0, a $1.3 \mathrm{~cm}(0.5$ in) thick vacuum jacket filled with multilayer insulation, a five percent tank ullage, and a tank accessory mass equal to 25 percent of the total tank mass. 
The parametric equations for the supercritical and cryogenic tank mass shown in Figure A1 are:

for supercritical tanks,

$$
\begin{aligned}
& \mathrm{M}_{\mathrm{T}, \mathrm{H}}=2.1463 \mathrm{M}_{\mathrm{H}}+.0761 \\
& \mathrm{M}_{\mathrm{T}, \mathrm{O}}=0.3908 \mathrm{M}_{\mathrm{O}}+.0701
\end{aligned}
$$

for cryogenic tanks,

$$
\begin{aligned}
& \mathrm{M}_{\mathrm{T}, \mathrm{H}}=\left(-4.96 \mathrm{E}-01 \mathrm{M}_{\mathrm{H}}^{2}+9.56 \mathrm{E}-01 \mathrm{M}_{\mathrm{H}}+2.74 \mathrm{E}-02\right) \\
& \mathrm{M}_{\mathrm{T}, \mathrm{O}}=\left(-4.72 \mathrm{E}-03 \mathrm{M}_{\mathrm{O}}^{2}+6.97 \mathrm{E}-02 \mathrm{M}_{\mathrm{O}}+2.17 \mathrm{E}-02\right)
\end{aligned}
$$

Where

$\mathrm{M}_{\mathrm{H}}=$ Hydrogen Mass, $\mathrm{kg}$

$\mathrm{M}_{\mathrm{O}}=$ Oxygen Mass, $\mathrm{kg}$

The reciprocal of the tankage power density that uses supercritical and cryogenic storage can be expressed as:

$$
\frac{1}{\rho_{\mathrm{T}}}=\frac{\mathrm{M}_{\mathrm{T}, \mathrm{H}}}{\mathrm{P}}+\frac{\mathrm{M}_{\mathrm{T}, \mathrm{O}}}{\mathrm{P}}+\frac{\mathrm{M}_{\mathrm{T}, \mathrm{W}}}{\mathrm{P}}
$$

Taking the reciprocal of Eq. (30) yields the tankage power density for supercritical and cryogenic storage.

$$
\rho_{\mathrm{T}}=\frac{1}{\left[\frac{\mathrm{M}_{\mathrm{T}, \mathrm{H}}}{\mathrm{P}}+\frac{\mathrm{M}_{\mathrm{T}, \mathrm{O}}}{\mathrm{P}}+\frac{\mathrm{M}_{\mathrm{T}, \mathrm{W}}}{\mathrm{P}}\right]}
$$

\section{Fuel Cell System Ancillary Equipment Power Density}

The ancillary equipment of a fuel cell system is used to accommodate the requirements of the fuel cell stack. Higher power stacks require higher reactant flows, which, in turn, require larger fluidic components and plumbing to accommodate increased flows and heat rejection requirements. Higher power fuel cell stacks require higher power (larger) electronics and wiring. On the other hand, the mass of the ancillary equipment does not seem particularly influenced by the amount of reactant used, but rather it seems more influenced by the rate at which that reactant is used. Based on these general observations, it appears reasonable to conclude that the greater the fuel cell system power the more massive the collection of ancillary equipment, and that the mass of ancillary equipment is relatively independent of the size of the reactant storage. Since the true relationship between the power of the fuel cell system and the mass of its attendant ancillary equipment is unknown, a linear approximation was assumed to be adequate for the range of fuel cell systems being considered in this study. This relationship can be expressed as:

$$
\mathrm{M}_{\mathrm{A}}=\mathrm{k}_{\mathrm{A}} \mathrm{P}
$$

Where

$\mathrm{k}_{\mathrm{A}}=$ Ancillary Equip. Factor, $\mathrm{kg} /$ watt

Rewriting Eq. (30)

$$
\frac{1}{\mathrm{k}_{\mathrm{A}}}=\frac{\mathrm{P}}{\mathrm{M}_{\mathrm{A}}}=\rho_{\mathrm{A}}
$$




\section{Fuel Cell System Packaging/Insulation Power Density}

The mass associated with the packaging and insulation for the fuel cell system is similarly difficult to estimate. It was assumed that items such as insulation and structural mass used to insulate and mount the fuel cell system were included. It was assumed that the mass of this portion of the fuel cell system could be estimated as a constant portion of the mass of all other fuel cell system components. That is, as the sum of the mass of the reactants, reactant tanks, fuel cell stack, or ancillary equipment increases, the mass of the insulation and packaging would proportionally increase. This is expressed as:

$$
\rho_{\mathrm{I}}=\frac{\eta_{\mathrm{e}} \xi}{\mathrm{t}_{\mathrm{d}} \mathrm{M}_{\mathrm{I}}}=\frac{\eta_{\mathrm{e}} \xi}{\mathrm{t}_{\mathrm{d}} \mathrm{k}_{\mathrm{I}}\left(\mathrm{M}_{\mathrm{F}}+\mathrm{M}_{\mathrm{S}}+\mathrm{M}_{\mathrm{T}}+\mathrm{M}_{\mathrm{A}}\right)}
$$

Where

$\mathrm{k}_{\mathrm{I}}=$ Packaging/Insulation Factor, dimensionless

Equation (34) can be rewritten as:

$$
\frac{1}{\rho_{\mathrm{I}}}=\mathrm{k}_{\mathrm{I}}\left[\frac{1}{\rho_{\mathrm{F}}}+\frac{1}{\rho_{\mathrm{S}}}+\frac{1}{\rho_{\mathrm{T}}}+\frac{1}{\rho_{\mathrm{A}}}\right]=\mathrm{k}_{\mathrm{I}}\left[\frac{1}{\rho_{\mathrm{F}}}+\frac{1}{\rho_{\mathrm{S}}}+\frac{1}{\rho_{\mathrm{T}}}+\mathrm{k}_{\mathrm{A}}\right]
$$

\section{Detailed Expression for Fuel Cell System Mass-Based Power and Energy Density}

Substituting Eqs. (6), (7), (25), (33), and (35) into Eq. (2) and developing expressions for the fuel cell system power density,

$$
\rho_{P}=\frac{1}{\left[1+k_{I}\right]\left[\left(\frac{t_{d}}{3661 \eta_{e}}\right)+\left(\frac{1}{V_{d} I_{d} A_{m}}\right)+\left(\frac{\left[\frac{P_{H} V_{M, H}}{\mu_{H}}+\frac{P_{O} V_{M, O}}{\mu_{O}}+\frac{P_{W} V_{M, W}}{\mu_{W}}\right] t_{d}}{65.898 \eta_{e}}\right)+k_{A}\right]}
$$

The fuel cell system power density equation when using supercritical or cryogenic storage is similar to Eq.(36) except that Eq. (31) is substituted for the tankage power density, and the Eqs. (26) to (29) are used for $\mathrm{M}_{\mathrm{T}, \mathrm{H}}$ and $\mathrm{M}_{\mathrm{T}, \mathrm{O}}$. This results in,

$$
\rho_{\mathrm{P}}=\frac{1}{\left[1+\mathrm{k}_{\mathrm{I}}\right]\left[\left(\frac{\mathrm{t}_{\mathrm{d}}}{3661 \eta_{\mathrm{e}}}\right)+\left(\frac{1}{\mathrm{~V}_{\mathrm{d}} \mathrm{I}_{\mathrm{d}} \mathrm{A}_{\mathrm{m}}}\right)+\left(\frac{\mathrm{M}_{\mathrm{T}, \mathrm{H}}}{\mathrm{P}}+\frac{\mathrm{M}_{\mathrm{T}, \mathrm{O}}}{\mathrm{P}}+\frac{\mathrm{M}_{\mathrm{T}, \mathrm{W}}}{\mathrm{P}}\right)+\mathrm{k}_{\mathrm{A}}\right]}
$$

The energy density of an energy storage device is also a key metric. The energy density is simply the power density multiplied by the discharge time. For primary fuel cells with high pressure gaseous storage the energy density is,

$$
\rho_{\mathrm{E}}=\frac{\mathrm{t}_{\mathrm{d}}}{\left[1+\mathrm{k}_{\mathrm{I}}\right]\left[\left(\frac{\mathrm{t}_{\mathrm{d}}}{3661 \eta_{\mathrm{e}}}\right)+\left(\frac{1}{\mathrm{~V}_{\mathrm{d}} \mathrm{I}_{\mathrm{d}} \mathrm{A}_{\mathrm{m}}}\right)+\left(\frac{\left[\frac{\mathrm{P}_{\mathrm{H}} \mathrm{V}_{\mathrm{M}, \mathrm{H}}}{\mu_{\mathrm{H}}}+\frac{\mathrm{P}_{\mathrm{O}} \mathrm{V}_{\mathrm{M}, \mathrm{O}}}{\mu_{\mathrm{O}}}+\frac{\mathrm{P}_{\mathrm{W}} \mathrm{V}_{\mathrm{M}, \mathrm{W}}}{\mu_{\mathrm{W}}}\right] \mathrm{t}_{\mathrm{d}}}{65.898 \eta_{\mathrm{e}}}\right)+\mathrm{k}_{\mathrm{A}}\right]}
$$


and for supercritical or cryogenic storage the energy density is

$$
\rho_{\mathrm{E}}=\frac{\mathrm{t}_{\mathrm{d}}}{\left[1+\mathrm{k}_{\mathrm{I}}\right]\left[\left(\frac{\mathrm{t}_{\mathrm{d}}}{366 \mathrm{\eta}_{\mathrm{e}}}\right)+\left(\frac{1}{\mathrm{~V}_{\mathrm{d}} \mathrm{I}_{\mathrm{d}} \mathrm{A}_{\mathrm{m}}}\right)+\left(\frac{\mathrm{M}_{\mathrm{T}, \mathrm{H}}}{\mathrm{P}}+\frac{\mathrm{M}_{\mathrm{T}, \mathrm{O}}}{\mathrm{P}}+\frac{\mathrm{M}_{\mathrm{T}, \mathrm{W}}}{\mathrm{P}}\right)+\mathrm{k}_{\mathrm{A}}\right]}
$$

Where

$\rho_{\mathrm{E}}=$ Energy density, watt-hr $/ \mathrm{kg}$

\section{B. Fuel Cell System Power and Energy Density Based on Volume}

Expressions similar to that developed for mass were developed for volumetric power density and volumetric energy density. The volumetric power density for fuel cells can be expressed as:

$$
\gamma_{\mathrm{P}}=\frac{\mathrm{P}}{\mathrm{V}_{\mathrm{T}}+\mathrm{V}_{\mathrm{S}}+\mathrm{V}_{\mathrm{A}}+\mathrm{V}_{\mathrm{I}}+\mathrm{V}_{\mathrm{V}}}
$$

Where

$\gamma_{\mathrm{P}} \quad=$ Volumetric power density, watt/liter

$\mathrm{V}_{\mathrm{T}}=$ Tankage volume, liter

$\mathrm{V}_{\mathrm{S}}=$ Fuel cell stack volume, liter

$\mathrm{V}_{\mathrm{A}}=$ Ancillary Equipment volume, liter

$\mathrm{V}_{\mathrm{I}} \quad$ Packaging/Insulation volume, liter

$\mathrm{V}_{\mathrm{V}}=$ Void Space volume, liter

Equation (40) can be rewritten as:

Where

$$
\gamma_{\mathrm{P}}=\frac{1}{\left(\frac{1}{\gamma_{\mathrm{T}}}\right)+\left(\frac{1}{\gamma_{\mathrm{S}}}\right)+\left(\frac{1}{\gamma_{\mathrm{A}}}\right)+\left(\frac{1}{\gamma_{\mathrm{I}}}\right)+\left(\frac{1}{\gamma_{\mathrm{V}}}\right)}
$$

$\gamma_{\mathrm{T}} \quad=$ Tankage volumetric. power density, watt/liter

$\gamma_{\mathrm{S}}=$ Stack volumetric. power density, watt/liter

$\gamma_{\mathrm{A}}=$ Ancillary Equip volumetric. power density, watt/liter

$\gamma_{\mathrm{I}}=$ Pack./Insulation volumetric. power density, watt/liter

$\gamma_{\mathrm{V}}=$ Void Space volumetric. power density, watt/liter

\section{Tankage Power Density}

The tankage volumetric power density can be expressed as:

$$
\gamma_{\mathrm{T}}=\frac{\eta_{\mathrm{e}} \xi}{\mathrm{t}_{\mathrm{d}} \mathrm{V}_{\mathrm{T}}}
$$

The volume of the tankage can be expressed as:

Where

$$
\mathrm{V}_{\mathrm{T}}=\mathrm{V}_{\mathrm{H}}+\mathrm{V}_{\mathrm{O}}+\mathrm{V}_{\mathrm{W}}+\frac{\mathrm{M}_{\mathrm{T}, \mathrm{H}}}{\widetilde{\rho}_{\mathrm{T}, \mathrm{H}}}+\frac{\mathrm{M}_{\mathrm{T}, \mathrm{O}}}{\widetilde{\rho}_{\mathrm{T}, \mathrm{O}}}+\frac{\mathrm{M}_{\mathrm{T}, \mathrm{W}}}{\widetilde{\rho}_{\mathrm{T}, \mathrm{W}}}
$$

$\widetilde{\rho}_{\mathrm{T}, \mathrm{H}}=$ Hydrogen tank material mean density, $\mathrm{kg} /$ liter

$\widetilde{\rho}_{\mathrm{T}, \mathrm{O}}=$ Oxygen tank material mean density, $\mathrm{kg} / \mathrm{liter}$

$\widetilde{\rho}_{\mathrm{T}, \mathrm{W}}=$ Water tank material mean density, $\mathrm{kg} /$ liter 
Substituting Eqs. (13) to (15) and (19) to (21) into Eq. (43),

$$
\mathrm{V}_{\mathrm{T}}=\mathrm{V}_{\mathrm{M}, \mathrm{H}}\left(1+\frac{\mathrm{P}_{\mathrm{H}}}{\widetilde{\rho}_{\mathrm{T}, \mathrm{H}} \mu_{\mathrm{H}}}\right) \mathrm{n}_{\mathrm{H}}+\mathrm{V}_{\mathrm{M}, \mathrm{O}}\left(1+\frac{\mathrm{P}_{\mathrm{O}}}{\widetilde{\rho}_{\mathrm{T}, \mathrm{O}} \mu_{\mathrm{O}}}\right) \mathrm{n}_{\mathrm{O}}+\mathrm{V}_{\mathrm{M}, \mathrm{W}}\left(1+\frac{\mathrm{P}_{\mathrm{W}}}{\widetilde{\rho}_{\mathrm{T}, \mathrm{W}} \mu_{\mathrm{W}}}\right) \mathrm{n}_{\mathrm{W}}
$$

Substituting Eq. (22) into Eq. (44),

$$
\mathrm{V}_{\mathrm{T}}=\left[\mathrm{V}_{\mathrm{M}, \mathrm{H}}\left(1+\frac{\mathrm{P}_{\mathrm{H}}}{\widetilde{\rho}_{\mathrm{T}, \mathrm{H}} \mu_{\mathrm{H}}}\right)+0.5 \mathrm{~V}_{\mathrm{M}, \mathrm{O}}\left(1+\frac{\mathrm{P}_{\mathrm{O}}}{\widetilde{\rho}_{\mathrm{T}, \mathrm{O}} \mu_{\mathrm{O}}}\right)+\mathrm{V}_{\mathrm{M}, \mathrm{W}}\left(1+\frac{\mathrm{P}_{\mathrm{W}}}{\widetilde{\rho}_{\mathrm{T}, \mathrm{W}} \mu_{\mathrm{W}}}\right)\right] \mathrm{n}_{\mathrm{W}}
$$

Substituting Eq. (24) into Eq. (45),

$$
\mathrm{V}_{\mathrm{T}}=\left[\mathrm{V}_{\mathrm{M}, \mathrm{H}}\left(1+\frac{\mathrm{P}_{\mathrm{H}}}{\widetilde{\rho}_{\mathrm{T}, \mathrm{H}} \mu_{\mathrm{H}}}\right)+0.5 \mathrm{~V}_{\mathrm{M}, \mathrm{O}}\left(1+\frac{\mathrm{P}_{\mathrm{O}}}{\widetilde{\rho}_{\mathrm{T}, \mathrm{O}} \mu_{\mathrm{O}}}\right)+\mathrm{V}_{\mathrm{M}, \mathrm{W}}\left(1+\frac{\mathrm{P}_{\mathrm{W}}}{\widetilde{\rho}_{\mathrm{T}, \mathrm{W}} \mu_{\mathrm{W}}}\right)\right]\left[\frac{\mathrm{M}_{\mathrm{F}}}{0.018}\right]
$$

Substituting Eq. (46) into Eq. (42), and replacing the ratio, $\xi / \mathrm{M}_{\mathrm{F}}$ with 3661 watt-hr per $\mathrm{kg}$, and simplifying the expression,

$$
\gamma_{\mathrm{T}}=\frac{65.898 \eta_{\mathrm{e}}}{\mathrm{t}_{\mathrm{d}}\left[\mathrm{V}_{\mathrm{M}, \mathrm{H}}\left(1+\frac{\mathrm{P}_{\mathrm{H}}}{\widetilde{\rho}_{\mathrm{T}, \mathrm{H}} \mu_{\mathrm{H}}}\right)+0.5 \mathrm{~V}_{\mathrm{M}, \mathrm{O}}\left(1+\frac{\mathrm{P}_{\mathrm{O}}}{\widetilde{\rho}_{\mathrm{T}, \mathrm{O}} \mu_{\mathrm{O}}}\right)+\mathrm{V}_{\mathrm{M}, \mathrm{W}}\left(1+\frac{\mathrm{P}_{\mathrm{W}}}{\widetilde{\rho}_{\mathrm{T}, \mathrm{W}} \mu_{\mathrm{W}}}\right)\right]}
$$

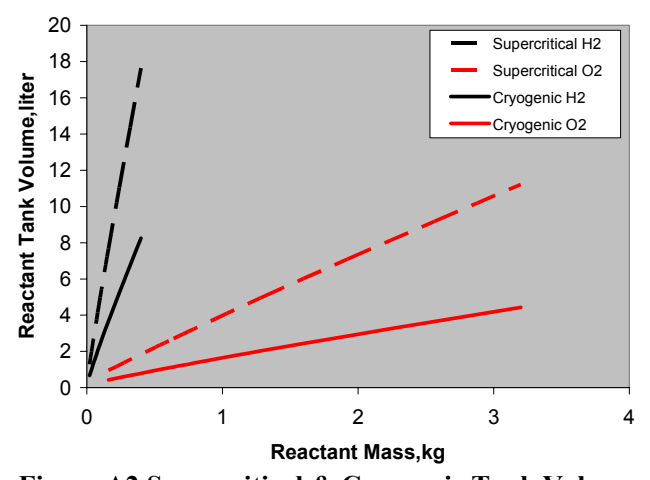

Figure A2 Supercritical \& Cryogenic Tank Volume
The tank volume associated with the supercritical fluid storage and the cryogenic storage was data generated internally at the NASA Glenn Research Center. Insulation for the tanks was included as part of the mass and volume of the tanks. The plots of that data are shown in Figures A2. These tanks were sized assuming a safety factor of 2.0 , a $1.3 \mathrm{~cm}(0.5 \mathrm{in})$ thick vacuum jacket filled with multilayer insulation, a five percent tank ullage, and a tank accessory mass equal to 25 percent of the total tank mass.

The parametric equations for the supercritical and cryogenic tank volume shown in Figure A2 are:

for supercritical tanks,

$$
\begin{aligned}
& \mathrm{V}_{\mathrm{T}, \mathrm{H}}=4.284 \mathrm{M}_{\mathrm{H}}+0.6543 \\
& \mathrm{~V}_{\mathrm{T}, \mathrm{O}}=3.3689 \mathrm{M}_{\mathrm{O}}+0.5341
\end{aligned}
$$

for cryogenic tanks,

$$
\begin{aligned}
\mathrm{V}_{\mathrm{T}, \mathrm{H}} & =19.842 \mathrm{M}_{\mathrm{H}}+0.4019 \\
\mathrm{~V}_{\mathrm{T}, \mathrm{O}} & =1.311 \mathrm{M}_{\mathrm{O}}+0.2898
\end{aligned}
$$

Where

$\mathrm{V}_{\mathrm{T}, \mathrm{H}}=$ Hydrogen Tank Overall Volume, liter

$\mathrm{V}_{\mathrm{T}, \mathrm{O}}=$ Oxygen Tank Overall Volume, liter 
The reciprocal of the tankage volumetric power density that uses supercritical and cryogenic storage can be expressed as:

$$
\frac{1}{\gamma_{\mathrm{T}}}=\frac{\mathrm{V}_{\mathrm{T}, \mathrm{H}}}{\mathrm{P}}+\frac{\mathrm{V}_{\mathrm{T}, \mathrm{O}}}{\mathrm{P}}+\frac{\mathrm{V}_{\mathrm{T}, \mathrm{W}}}{\mathrm{P}}
$$

Taking the reciprocal of Eq. (50) yields the tankage volumetric power density for supercritical and cryogenic storage.

$$
\gamma_{\mathrm{T}}=\frac{1}{\left[\frac{\mathrm{V}_{\mathrm{T}, \mathrm{H}}}{\mathrm{P}}+\frac{\mathrm{V}_{\mathrm{T}, \mathrm{O}}}{\mathrm{P}}+\frac{\mathrm{V}_{\mathrm{T}, \mathrm{W}}}{\mathrm{P}}\right]}
$$

\section{Fuel Cell Stack Power Density}

The fuel cell stack volumetric power density can be expressed as:

$$
\gamma_{\mathrm{S}}=\mathrm{V}_{\mathrm{d}} \mathrm{I}_{\mathrm{d}} \mathrm{A}_{\mathrm{v}}
$$

Where

$\mathrm{A}_{\mathrm{v}}=$ Active area per unit volume, $\mathrm{m}^{2} /$ liter

\section{Ancillary Equipment Power Density}

The ancillary equipment volumetric power density can be expressed as:

$$
\gamma_{\mathrm{A}}=\rho_{\mathrm{A}} \tilde{\rho}_{\mathrm{A}}
$$

Where

$\widetilde{\rho}_{\mathrm{A}}=$ Mean Material density of ancillary equipment, $\mathrm{kg} / \mathrm{liter}$

\section{Packaging/Insulation Power Density}

Similarly, the volumetric power density for the packaging and insulation can be expressed as:

$$
\gamma_{\mathrm{I}}=\rho_{\mathrm{I}} \widetilde{\rho}_{\mathrm{I}}
$$

Where

$\widetilde{\rho}_{\mathrm{I}}=$ Mean material density of packaging/insulation, $\mathrm{kg} / \mathrm{liter}$

\section{Void Space Power Density}

The volumetric power density of the void space can be expressed as:

$$
\gamma_{\mathrm{v}}=\frac{\eta_{\mathrm{e}} \xi}{\mathrm{t}_{\mathrm{d}} \mathrm{V}_{\mathrm{V}}}
$$

The void space was assumed to be a percentage of the combined volume of all other fuel cell system components.

$$
\mathrm{V}_{\mathrm{V}}=\mathrm{k}_{\mathrm{V}}\left(\mathrm{V}_{\mathrm{T}}+\mathrm{V}_{\mathrm{S}}+\mathrm{V}_{\mathrm{A}}+\mathrm{V}_{\mathrm{I}}\right)
$$


Where

$\mathrm{k}_{\mathrm{V}} \quad=$ Void Space Factor, dimensionless

Substituting Eq. (58) into Eq. (57), and re-writing Eq. (57),

$$
\frac{1}{\gamma_{\mathrm{V}}}=\mathrm{k}_{\mathrm{V}}\left(\frac{1}{\gamma_{\mathrm{T}}}+\frac{1}{\gamma_{\mathrm{S}}}+\frac{1}{\gamma_{\mathrm{A}}}+\frac{1}{\gamma_{\mathrm{I}}}\right)
$$

\section{Detailed Expression for Fuel Cell System Volumetric Power and Energy Density}

Substituting Eq. (59) into Eq. (41) and simplifying the expression for primary fuel cell volumetric power density yields:

$$
\gamma_{\mathrm{P}}=\frac{1}{\left[1+\mathrm{k}_{\mathrm{V}}\right]\left[\left(\frac{1}{\gamma_{\mathrm{T}}}\right)+\left(\frac{1}{\gamma_{\mathrm{S}}}\right)+\left(\frac{1}{\gamma_{\mathrm{A}}}\right)+\left(\frac{1}{\gamma_{\mathrm{I}}}\right)\right]}
$$

Substituting Eqs. (47) and (54) to (56) into Eq. (60) provides the expression for primary fuel cell volumetric power density when using high pressure gaseous storage:

$$
\gamma_{\mathrm{P}}=\frac{1}{\left[1+\mathrm{k}_{\mathrm{V}}\right]\left[\frac{\mathrm{t}_{\mathrm{d}}\left[\mathrm{V}_{\mathrm{M}, \mathrm{H}}\left(1+\frac{\mathrm{P}_{\mathrm{H}}}{\widetilde{\rho}_{\mathrm{T}, \mathrm{H}} \mu_{\mathrm{H}}}\right)+0.5 \mathrm{~V}_{\mathrm{M}, \mathrm{O}}\left(1+\frac{\mathrm{P}_{\mathrm{O}}}{\widetilde{\rho}_{\mathrm{T}, \mathrm{O}} \mu_{\mathrm{O}}}\right)+\mathrm{V}_{\mathrm{M}, \mathrm{W}}\left(1+\frac{\mathrm{P}_{\mathrm{W}}}{\widetilde{\rho}_{\mathrm{T}, \mathrm{W}} \mu_{\mathrm{W}}}\right)\right]}{65.898 \eta_{\mathrm{e}}}+\left(\frac{1}{\mathrm{~V}_{\mathrm{d}} \mathrm{I}_{\mathrm{d}} \mathrm{A}_{\mathrm{V}}}\right)+\left(\frac{1}{\rho_{\mathrm{A}} \widetilde{\rho}_{\mathrm{A}}}\right)+\left(\frac{1}{\rho_{\mathrm{I}} \widetilde{\rho}_{\mathrm{I}}}\right)\right]}
$$

The fuel cell system volumetric power density equation when using supercritical or cryogenic storage is similar to Eq. (61) except that Eq. (52) is substituted for the tankage volumetric power density, and the Eqs. (48 to (51) are used for $\mathrm{V}_{\mathrm{T}, \mathrm{H}}$ and $\mathrm{V}_{\mathrm{T}, \mathrm{O}}$. This results in,

$$
\gamma_{\mathrm{P}}=\frac{1}{\left[1+\mathrm{k}_{\mathrm{V}}\right]\left[\left[\frac{\mathrm{V}_{\mathrm{T}, \mathrm{H}}}{\mathrm{P}}+\frac{\mathrm{V}_{\mathrm{T}, \mathrm{O}}}{\mathrm{P}}+\frac{\mathrm{V}_{\mathrm{T}, \mathrm{W}}}{\mathrm{P}}\right]+\left(\frac{1}{\mathrm{~V}_{\mathrm{d}} \mathrm{I}_{\mathrm{d}} \mathrm{A}_{\mathrm{V}}}\right)+\left(\frac{1}{\rho_{\mathrm{A}} \widetilde{\rho}_{\mathrm{A}}}\right)+\left(\frac{1}{\rho_{\mathrm{I}} \widetilde{\rho}_{\mathrm{I}}}\right)\right]}
$$

The volumetric energy density is obtained by multiplying the power density by discharge time. For primary fuel cells which use high pressure gaseous storage, 


$$
\gamma_{\mathrm{E}}=\frac{\mathrm{t}_{\mathrm{d}}}{\left[1+\mathrm{k}_{\mathrm{V}}\right]\left[\frac{\mathrm{t}_{\mathrm{d}}\left[\mathrm{V}_{\mathrm{M}, \mathrm{H}}\left(1+\frac{\mathrm{P}_{\mathrm{H}}}{\widetilde{\rho}_{\mathrm{T}, \mathrm{H}} \mu_{\mathrm{H}}}\right)+0.5 \mathrm{~V}_{\mathrm{M}, \mathrm{O}}\left(1+\frac{\mathrm{P}_{\mathrm{O}}}{\widetilde{\rho}_{\mathrm{T}, \mathrm{O}} \mu_{\mathrm{O}}}\right)+\mathrm{V}_{\mathrm{M}, \mathrm{W}}\left(1+\frac{\mathrm{P}_{\mathrm{W}}}{\widetilde{\rho}_{\mathrm{T}, \mathrm{W}} \mu_{\mathrm{W}}}\right)\right]}{65.898 \eta_{\mathrm{e}}}+\left(\frac{1}{\mathrm{~V}_{\mathrm{d}} \mathrm{I}_{\mathrm{d}} \mathrm{A}_{\mathrm{V}}}\right)+\left(\frac{1}{\rho_{\mathrm{A}} \widetilde{\rho}_{\mathrm{A}}}\right)+\left(\frac{1}{\rho_{\mathrm{I}} \widetilde{\rho}_{\mathrm{I}}}\right)\right]}
$$

and for supercritical or cryogenic storage the volumetric energy density is

$$
\gamma_{\mathrm{E}}=\frac{\mathrm{t}_{\mathrm{d}}}{\left[1+\mathrm{k}_{\mathrm{V}}\right]\left[\left[\frac{\mathrm{V}_{\mathrm{T}, \mathrm{H}}}{\mathrm{P}}+\frac{\mathrm{V}_{\mathrm{T}, \mathrm{O}}}{\mathrm{P}}+\frac{\mathrm{V}_{\mathrm{T}, \mathrm{W}}}{\mathrm{P}}\right]+\left(\frac{1}{\mathrm{~V}_{\mathrm{d}} \mathrm{I}_{\mathrm{d}} \mathrm{A}_{\mathrm{V}}}\right)+\left(\frac{1}{\rho_{\mathrm{A}} \widetilde{\rho}_{\mathrm{A}}}\right)+\left(\frac{1}{\rho_{\mathrm{I}} \widetilde{\rho}_{\mathrm{I}}}\right)\right]}
$$

Where

$\gamma_{\mathrm{E}}=$ Volumetric energy density, watt-hr/liter

\section{References}

${ }^{1}$ Kenneth A. Burke, "High Energy density Regenerative Fuel Cell Systems for Terrestrial Applications," NASA/TM-1999-209429, SAE 00-01-2600, July 1999.

${ }^{2}$ Kenneth A. Burke, "Fuel Cells for Space Science Applications," NASA/TM-2003-212730, AIAA-2003-5938 July 2003.

${ }^{3}$ Detailed specifications of General Motors Hy-wire ${ }^{\mathrm{TM}}$ advanced technology vehicle available at http://www.gm.com/company/gmability/adv_tech/images/fact_sheets/hywire_specs.html

${ }^{4}$ Detailed of specifications Nuvera Fuel Cells Adromeda ${ }^{\mathrm{TM}}{ }^{-}$HCS-575 Fuel Cell Satck Series available at http://www.nuvera.com/markets/androm.php

${ }^{5}$ WWW.Fuel Cells.org, Fuel Cells 2000 Online Fuel Cell Information Resource, available at http://www.fuelcells.org/info/charts/TransTechnical.pdf

${ }^{6}$ Specifications of Manhatten Scientifics, Inc. midrange fuel cell technology, available at http://www.mhtx.com/novars/index.htm

${ }^{7}$ Specifications of Ballard Power Systems Mark 902 Fuel Cell Module, available at http://www.ballard.com/be_a_customer/transportation/fuel_cell_modules/mark_902\#

${ }^{8}$ Data obtained from NSTS 1988 News Reference Manual, available at http://science.ksc.nasa.gov/shuttle/technology/sts-newsref/stsref-toc.html

${ }^{9}$ Data obtained from Carleton Technologies Inc. 504 McCormick Drive, Glen Burnie, MD. 21061.

${ }^{10}$ Data obtained from HyPerComp Engineering, Inc, 1080 N. Main St. Suite 2, Brigham City, Utah, 84302.

11“'Mechanical Engineers' Handbook", Chapter 9 Composite Materials and Mechanical Design, $2^{\text {nd }}$ Edition, Myer Kutz, Editor, 1998 Wiley and Sons, Inc. ISBN 0-471-13007-9.

${ }^{12}$ Data obtained from Westbridge PET Containers\#10 $310314^{\text {th }}$ Ave. N.E.Calgary, Alberta, Canada T2A 7N61, available at http://www.westbridge.ca/products/car_1.html

13“"Energy Storage Technology for Future Space Science Missions," JPL D-30268 Jet Propulsion Laboratory, Issued November 2004. 


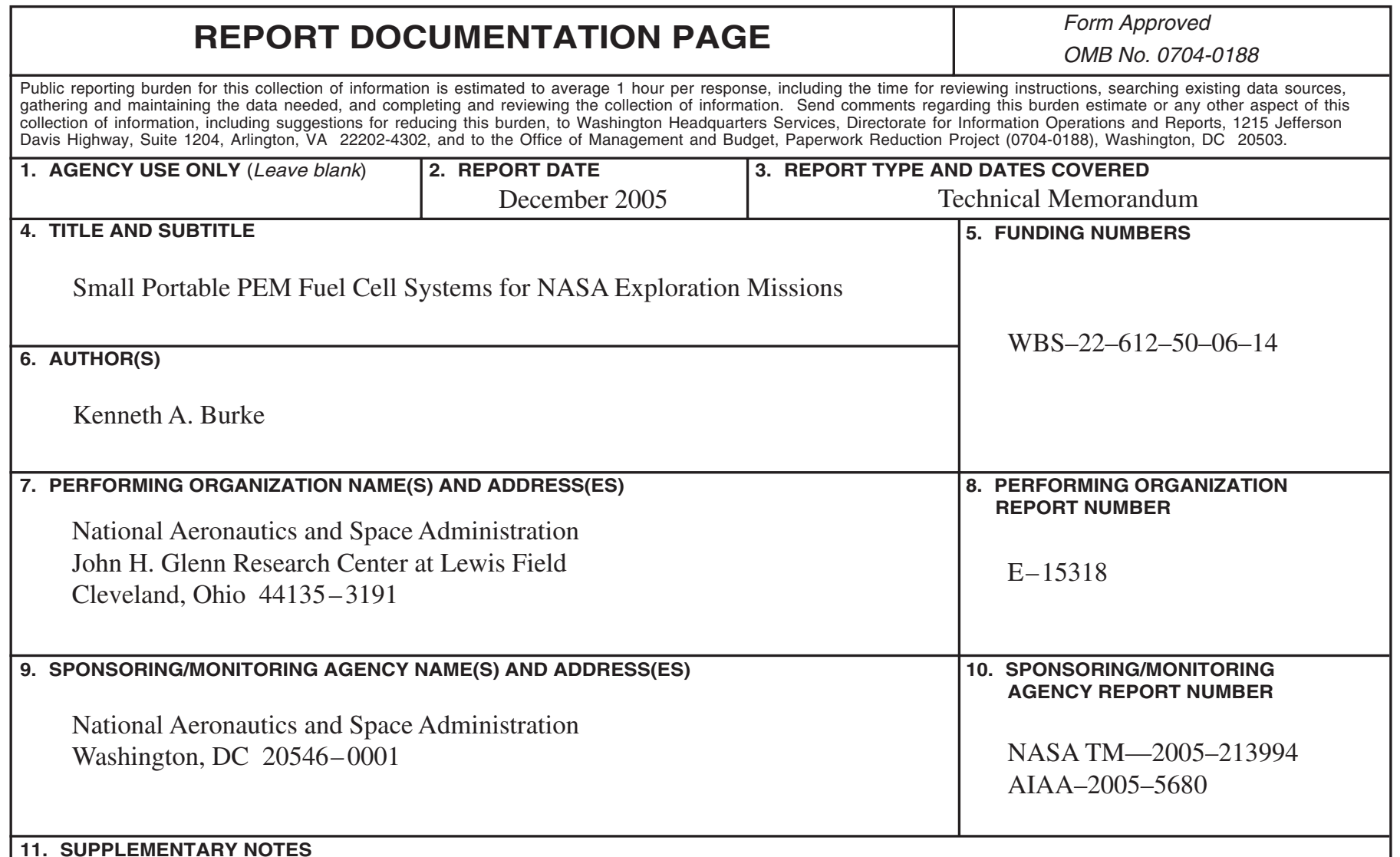

\section{SUPPLEMENTARY NOTES}

Prepared for the Third International Energy Conversion Engineering Conference sponsored by the American Institute of Aeronautics and Astronautics, San Francisco, California, August 15-18, 2005. Responsible person, Kenneth A. Burke, organization code RPC, 216-433-8308.

\section{2a. DISTRIBUTION/AVAILABILITY STATEMENT}

12b. DISTRIBUTION CODE

Unclassified - Unlimited

Subject Categories: 20 and 44

Available electronically at http://gltrs.grc.nasa.gov

This publication is available from the NASA Center for AeroSpace Information, 301-621-0390.

\section{ABSTRACT (Maximum 200 words)}

Oxygen-Hydrogen PEM-based fuel cell systems are being examined as a portable power source alternative in addition to advanced battery technology. Fuel cell power systems have been used by the Gemini, Apollo, and Space Shuttle programs. These systems have not been portable, but have been integral parts of their spacecraft, and have used reactants from a separate cryogenic supply. These systems typically have been higher in power. They also have had significant ancillary equipment sections that perform the pumping of reactants and coolant through the fuel cell stack and the separation of the product water from the unused reactant streams. The design of small portable fuel cell systems will be a significant departure from these previous designs. These smaller designs will have very limited ancillary equipment, relying on passive techniques for reactant and thermal management, and the reactant storage will be an integral part of the fuel cell system. An analysis of the mass and volume for small portable fuel cell systems was done to evaluate and quantify areas of technological improvement. A review of current fuel cell technology as well as reactant storage and management technology was completed to validate the analysis and to identify technology challenges.

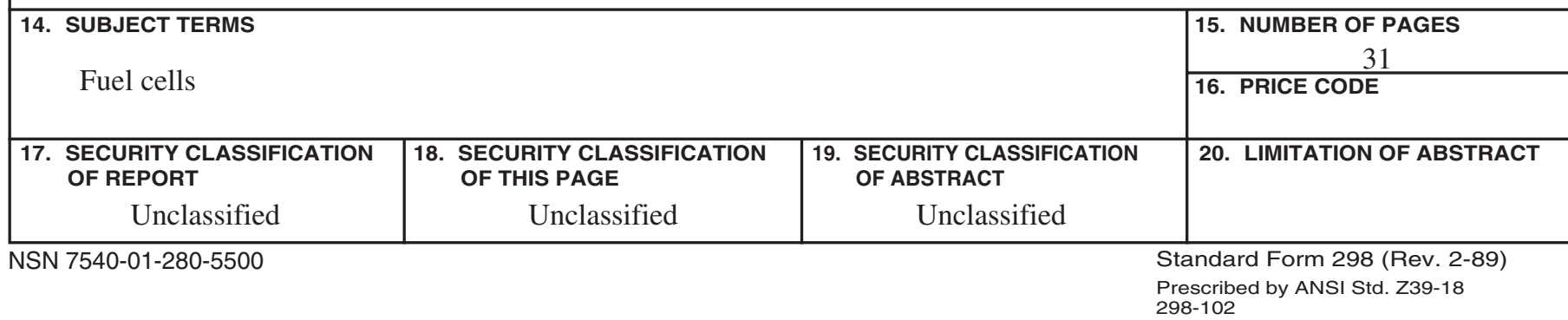



